\title{
Organic matter in river-influenced continental margin sediments: The land-ocean and climate linkage at the Late Quaternary Congo fan (ODP Site 1075)
}

\author{
Jens Holtvoeth \\ Fachbereich Geowissenschaften der Universität Bremen, Klagenfurter Str., D-28259 Bremen, Germany \\ (holtvoet@uni-bremen.de)
}

\section{Thomas Wagner}

Marine Chemistry and Geochemistry Department, Woods Hole Oceanographic Institution, Woods Hole, Massachusetts, USA (twagner@whoi.edu)

Also at Department of Geosciences, University of Bremen, Bremen, Germany

\section{Carsten J. Schubert}

Limnological Research Center (EAWAG), Seestrasse 79, CH-6047 Kastanienbaum, Switzerland (carsten.schubert@eawag.ch)

[1] Late Quaternary sections (1.2 Ma) of ODP-Site 1075 from the Congo deep-sea fan are investigated to reconstruct variations of terrigenous organic matter supply to the eastern equatorial Atlantic. To characterize the organic matter $(\mathrm{OM})$ with regard to marine and terrigenous amounts we used elemental analysis $(\mathrm{C}, \mathrm{N}, \mathrm{S})$, stable carbon isotopes (bulk $\delta^{13} \mathrm{C}_{\mathrm{org}}$ ), Rock-Eval pyrolysis, and terrigenous biomarkers (lignin phenols from $\mathrm{CuO}$ oxidation). The records of total organic carbon (TOC) contents, $\mathrm{C}_{\text {org }} / \mathrm{N}_{\text {tot }}$ ratios, bulk OM degradation rates $\left(\mathrm{C}_{\mathrm{org}} / \mathrm{C}_{\mathrm{org}}{ }^{*}\right)$, and the ratios of hydrocarbons (HC) from low-mature versus $\mathrm{HC}$ from high-mature $\mathrm{OM}(\mathrm{lm} / \mathrm{hm})$ reveal pronounced cyclic changes in OM abundance, preservation, and reactivity that are closely related to the precessional controlled record of insolation, and thus, to variations in upwelling intensity and fluvial run-off. Primary productivity off the Congo is stimulated by both, enhanced nutrient supply in response to trade-induced upwelling during arid African climates (insolation minima) and fluvial nutrient delivery during humid stages (following insolation maxima), especially due to the contribution of dissolved silica that is taken up preferably by diatoms. However, results stemming from a multiparameter approach reveal that the fluvial supply of degraded OM and black carbon (BC) associated with fine-grained sediments from soil erosion is a decisive factor for the preservation of marine OM and, in addition, significantly influences the geochemical signature of bulk and terrigenous OM. Riverine and eolian supply of $\mathrm{C}_{4}$ plant matter, as well as enhanced concentrations of $\mathrm{BC}$, during arid and arid-to-humid transitional climate stages, may lead to a severe underestimation of terrigenous organic carbon, if its amount is calculated from bulk isotopic ratios using binary end-member models. During the humid stages, it is the massive supply of ${ }^{13} \mathrm{C}$-enriched soil $\mathrm{OM}$ with low $\mathrm{C}_{\text {org }} / \mathrm{N}_{\text {tot }}$ ratios that may suggest a mainly marine composition of bulk OM. In fact, terrigenous OM governs bulk OM geochemical signatures in the sediments of the Congo deep-sea fan, a result that is contradictory to earlier studies, especially to the conventional interpretation of the bulk $\delta^{13} \mathrm{C}_{\text {org }}$ signal.

Components: 14,152 words, 11 figures, 2 tables.

Keywords: Congo deep-sea fan; terrestrial organic matter; lignin; organic matter reactivity; insolation forcing; Quaternary tropical Atlantic. 
Index Terms: 4863 Oceanography: Biological and Chemical: Sedimentation; 4805 Oceanography: Biological and Chemical: Biogeochemical cycles (1615); 1620 Global Change: Climate dynamics (3309); 4850 Oceanography: Biological and Chemical: Organic marine chemistry.

Received 17 June 2003; Revised 2 September 2003; Accepted 9 September 2003; Published 31 December 2003.

Holtvoeth, J., T. Wagner, and C. J. Schubert, Organic matter in river-influenced continental margin sediments: The landocean and climate linkage at the Late Quaternary Congo fan (ODP Site 1075), Geochem. Geophys. Geosyst., 4(12), 1109, doi:10.1029/2003GC000590, 2003.

\section{Introduction}

[2] The significance of terrigenous $\mathrm{OM}$ in the contemporaneous ocean [see Eglinton and Repeta, 2003] and in deep-sea sediments is an important yet currently poorly constrained aspect of the global organic carbon cycle. Several recent studies argue that supply of riverine and eolian organic matter $(\mathrm{OM})$ plays a greater role in bulk organic carbon accumulation in deep-sea basins than is commonly considered [e.g., Verardo and Ruddiman, 1996; Meyers, 1997; Goñi et al., 1998; Wagner and Dupont, 1999; Onstad et al., 2000; Stein and Fahl, 2000; Wagner, 2000; Stein and McDonald, 2003; Wagner et al., 2003]. Moreover, the influence of climate variations on the quantity and quality of terrigenous $\mathrm{OM}$ exported to the ocean is not well understood. The conventional assumption is that deposition of terrigenous $\mathrm{OM}$ is restricted to the shelf and upper slope during periods of high sea level stand [e.g., Jones, 1983]. Together with generally elevated marine productivity, continental margins are considered primary sites for modern organic carbon production, burial, and export [Bauer and Druffel, 1998]. The established view of a deep ocean devoid of significant terrigenous OM contributions is challenged by investigations on the modern Congo fan [Müller et al., 1994; Wagner et al., 2003] that clearly identify this deep-sea fan as a corridor where terrigenous OM escapes the shelf and is transported to the abyssal eastern tropical Atlantic Ocean. The dramatic effect of glacial sea level lowstands on the downslope entrainment of terrigenous organic carbon has been shown for the Late Quaternary Amazon Fan [Schneider et al., 1997a; Schlünz et al., 1999]. There, it has been proposed that part of the terrigenous OM from the Amazon reaches as far as the Ceará Rise
[Rühlemann et al., 1996] and may even be advected to the deep Atlantic basins [Zabel et al., 1999].

[3] The Congo River is the most important source of terrigenous organic carbon in the modern eastern Equatorial Atlantic [Showers and Angle, 1986]. Previous high-resolution geochemical studies at site GeoB 1008 on the southern Congo deep-sea fan [Schneider et al., 1994, 1997b] suggest that organic sedimentation over the last 200 kyrs was governed by orbital-forced fluctuations in atmospheric circulation that triggered upwelling and marine productivity along the western equatorial African continental margin as well as continental aridity-humidity cycles [Pokras and Mix, 1985; deMenocal, 1995]. The dominance of precessionalforced insolation changes on African climate and thus on the distribution of vegetation zones has been confirmed by numerous marine pollen records from the eastern equatorial Atlantic [e.g., Frédoux, 1994; Ning and Dupont, 1997; Jahns et al., 1998; Dupont, 1999; Dupont et al., 2000]. The general link between organic sedimentation and orbital forcing persisted over the past 1.2 Myrs on the Congo deep-sea fan [Holtvoeth et al., 2001]. The frequency in orbital forcing, however, experienced a fundamental change from dominant obliquity cycles to the large-amplitude eccentricity cycles of the Milankovitch chron (past 0.7 my) associated with the Mid-Pleistocene Revolution [Dupont et $a l ., 2001]$. This general transition in climate forcing was characterized by prominent changes in atmospheric moisture content that controlled aridity on the African continent via fluctuations in seasurface temperature and strength of the African monsoon [Schefuß et al., 2003].

[4] In addition to fluctuations in quantity and composition of bulk sedimentary OM in sediments 


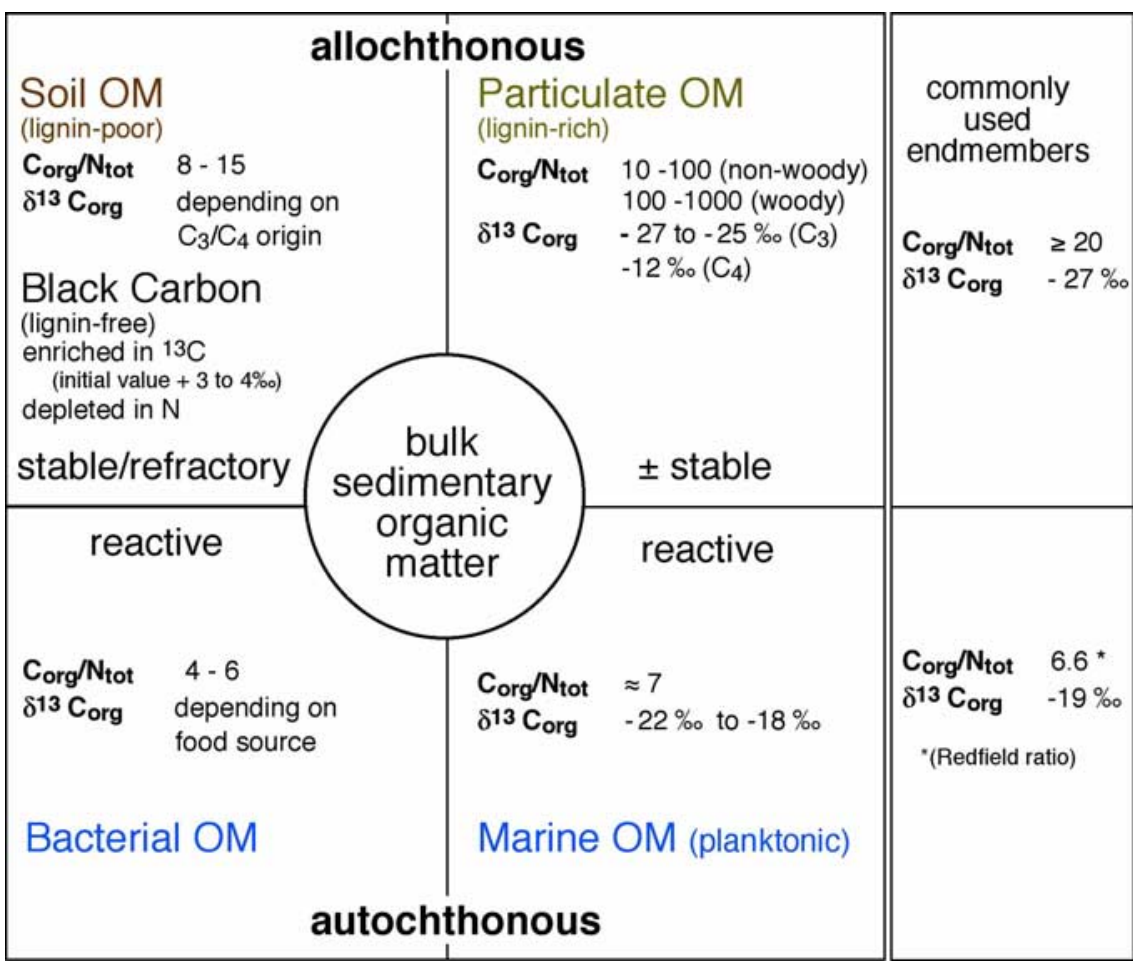

Figure 1. Sources of organic matter $(\mathrm{OM})$ in river-influenced continental margin sediments and geochemical properties of selected, commonly used diagnostic parameters [according to Fry and Sherr, 1984; Hedges et al., 1986; Müller et al., 1994; Goñi and Hedges, 1995; Hedges et al., 1997; Ruttenberg and Goñi, 1997].

from the late Quaternary Congo Fan, Holtvoeth et al. [2001] also identified pronounced cyclic variations in reactivity of the bulk OM at ODP Site 1075. These "bulk OM reactivity-cycles" were attributed to changes in the relative proportions of oxidized versus non-oxidized terrigenous (mainly inertinite versus vitrinite) and autochthonous (marine and bacterial) organic compounds. Since bulk OM reactivity is the primary factor determining microbial turnover rates in marine deposits (see reviews in Jørgensen [1999] and Rullkötter [1999]), it is essential to better assess and characterize the different sources and fate of reactive OM. In such cases a complex mixture of inputs from different additional sources must be considered. In addition to algal sources potential contributions include (1) particulate $\mathrm{OM}$ from relatively fresh vascular plant tissue (POM), (2) pre-oxidized soilderived OM, (3) thermally altered (burned) OM (black carbon/BC, comprising a continuum of combustion products with decreasing reactivity from slightly charred biomass to char, charcoal and soot) [Schmidt and Noack, 2000], and (4) OM from bacterial biomass (Figure 1). Variable admixture of this broad spectrum of continental, marine, and microbial $\mathrm{OM}$ and subsequent selective degradation of specific organic sub-fractions may result in a complex signature for the residual TOC in the geological record. This combination of inputs and degradation processes confounds attempts to establish conservative factors, such as changes in $\mathrm{OM}$ supply, climate or ocean properties.

[5] In this study we combine established bulk organic geochemical parameters $\left(\delta^{13} \mathrm{C}_{\text {org }}, \mathrm{C}_{\text {org }} / \mathrm{N}_{\text {tot }}\right)$ and parameters sensitive to degradation (sulfate reduction index, $\mathrm{C}_{\text {org }} / \mathrm{C}_{\text {org }}{ }^{*}$ ) as well as reactivity of bulk OM $(\mathrm{lm} / \mathrm{hm}$ ratio) with molecular parameters from lignin oxidation $(\mathrm{S} / \mathrm{V}, \mathrm{C} / \mathrm{V}, \Lambda$, acid/ aldehyde ratios) to develop a model that explains the record of organic carbon burial in river-influenced continental margin sediments. Although desirable, this study does not provide the properties for each of the individual organic compounds contributing to the bulk OM but addresses only the principle characteristics of the bulk OM. Our 
research area is the Congo deep-sea fan at ODP Site 1075 and the stratigraphic interval spans the past 1.2 million years (approximately 120 meters section).

\section{Depositional Setting and Geological Background}

[6] The Congo River drains the second largest catchment area of the world and contributes 3.9\% $\left(13^{*} 10^{6} \mathrm{t}\right.$ C/year) of the global annual supply of terrigenous organic carbon into the ocean [Martins and Probst, 1991]. About 38\% (1300 km $3 /$ year) of the yearly run-off from Africa occurs through the Congo [N'Kounkou and Probst, 1987]. The strong influence of the river load on long-term marine sedimentation on the adjacent continental margin is evident from the existence of the Congo deep-sea fan. The Congo reveals 11 to 17 times lower suspended sediment loads than other major rivers [Schlünz and Schneider, 2000]. This difference is attributed to the morphology of the catchment area and regional precipitation patterns [Eisma, 1982; N'Kounkou and Probst, 1987]. Owing to the narrow ( $\sim 50 \mathrm{~km}$ wide) continental shelf in front of the Congo mouth and the presence of a central canyon that begins within the estuary of the river (Figure 2), part of the riverine terrigenous $\mathrm{OM}$ is transported directly to the deep-sea even during modern and past interglacial sea level highstands. Therefore late Quaternary changes in the supply of terrigenous $\mathrm{OM}$ should be well preserved in sediments of the Congo deep-sea fan.

[7] The modern vegetation in the Congo catchment area is dominated by tropical rain forest whose productivity is governed by the West-African monsoon [Ning and Dupont, 1997]. Late Quaternary insolation cycles strongly influenced African paleoclimate that fluctuated from arid conditions during cold glacial and interglacial periods to humid conditions associated with their warm counterparts. Marine palynological records show that the savannah belts on both sides of the equator expanded during dryer climatic conditions to replace the tropical rain forest as the dominant type of vegetation in the Congo catchment area [e.g., Frédoux, 1994; Jahns et al., 1998; Dupont et al., 2001]. The African grass-savannah dominates at the transition to full desert conditions and exhibits better growth conditions for $\mathrm{C}_{4}$ plants [Tyson, 1995]. Climate-driven changes in atmospheric $\mathrm{CO}_{2}$ concentrations caused a repetitive expansion or contraction of the $\mathrm{C}_{4}$ plant habitat [Jolly and Haxeltine, 1997; Cerling et al., 1997; Huang et al., 1999]. It is therefore expected that the amount and composition of terrigenous OM exported by the Congo River and supplied as part of eolian dust has fluctuated in response to the Late Quaternary glacial-interglacial cycles. Compound-specific carbon isotope data of terrigenous plant waxes (long-chain $\mathrm{C}_{25}$ to $\mathrm{C}_{35}$ odd-numbered n-alkanes) analysed in surface sediments of the eastern Angola Basin and in 1.2 to $0.45 \mathrm{Ma}$ old sections at ODP Site 1077, located down-slope ODP Site 1075 on the Congo fan, confirm regional and temporal fluctuations in wind-transported terrigenous $\mathrm{OM}$ from $\mathrm{C}_{4}$ plant sources and thus African aridity [Schefuß et al., 2003].

\section{Lithology, Stratigraphy, and Methods}

[8] Late Quaternary sections of Site 1075, situated on the northern part of the Congo deep-sea fan in $2996 \mathrm{~m}$ water depth, are a bioturbated monotonous sequence of greenish-grey clay containing relicts of diatoms and varying amounts of nannofossils, e.g., silicoflagellates, radiolaria, and foraminifera [Wefer et al., 1998]. The stratigraphy of Late Quaternary sections of ODP Site 1075 was originally set up by correlation of high-resolution magnetic susceptibility records of Site 1075 and the neighboring

Figure 2. (opposite) African vegetation zones under modern and past glacial climatic conditions [Adams and Faure, 1995, www.soton.ac.uk/ tjms/adams1.html] with superimposed modern Congo catchment area (red line). (a) Surface and subsurface currents, and highly productive areas in the modern eastern Equatorial Atlantic (modified after Schneider et al. [1994]). Black arrows identify cold surface currents, open arrows warm surface currents, and hatched arrows undercurrents. High-productivity areas are marked by different hatchings: narrow, river plume with river-induced upwelling; medium, oceanic upwelling with shallow thermocline, thermal domes and fronts; wide, coastal upwelling. (b) Position of ODP Sites 1075 and 1077 on the Congo deep-sea fan [Wefer et al., 1998]. 


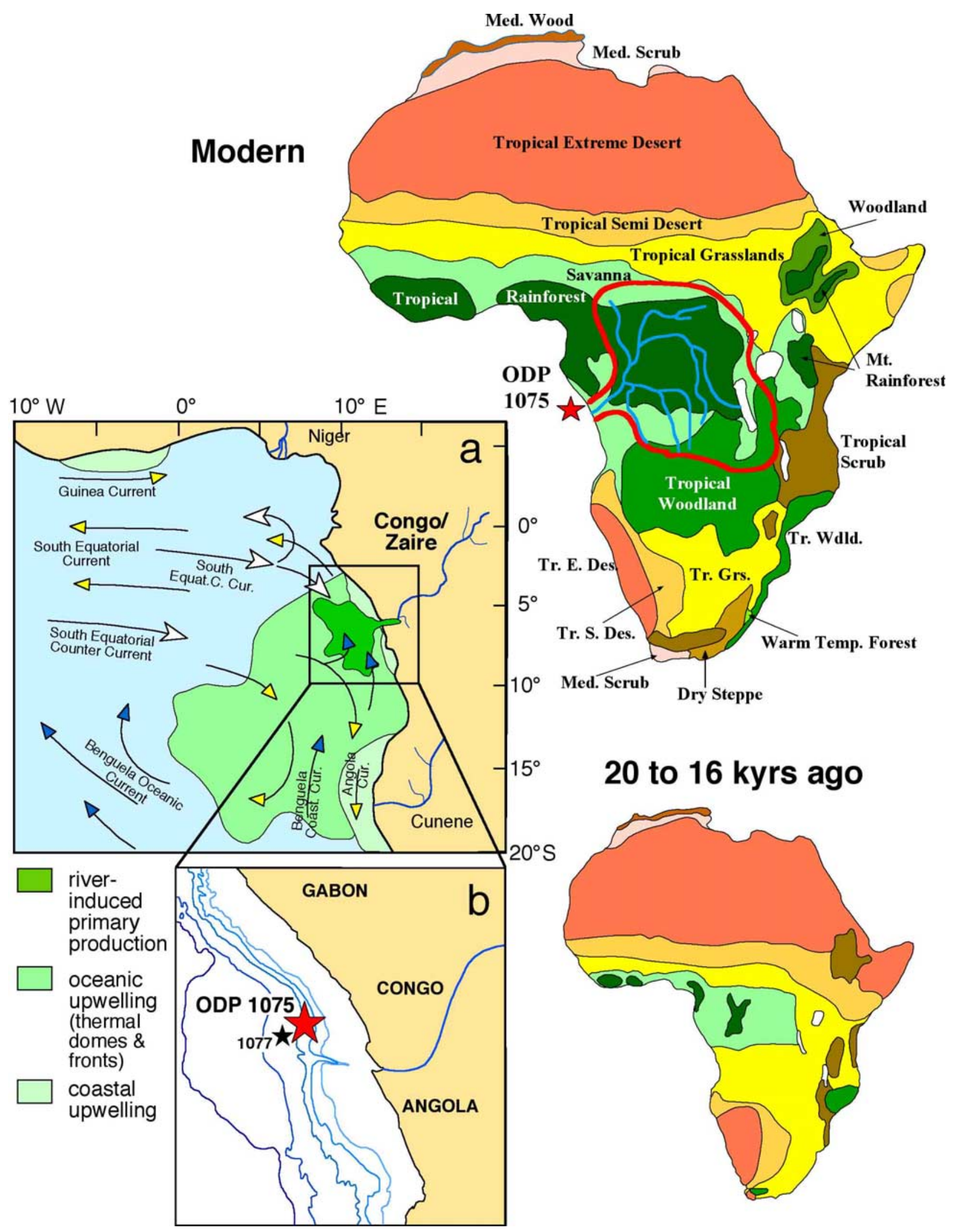


Site 1077 (see Figure 2b for core positions), where a stratigraphy based on oxygen isotope ratios of Globigerina ruber pink was established by Dupont et al. [2001]. Both magnetic susceptibility records reveal pronounced minima and maxima, which parallel each other and apparently follow typical glacial/interglacial patterns. Generally, interglacial (more humid) stages are characterized by higher contents of magnetizable minerals compared to glacial (more arid) stages due to an enhanced riverine run-off during the former intervals. To accommodate the excellent visual correlation of the high-frequency (precessional) TOC records from both sites in sections younger than $1 \mathrm{Ma}$ we refine the age model for ODP Site 1075 by correlation of the TOC profiles between 0 and $108.3 \mathrm{mcd}$ (Table 1). Below, from 108.3 to $126.5 \mathrm{mcd}$, we used the stratigraphic framework of Dupont et al. [2001].

[9] Total carbon, total organic carbon (TOC) and sulfur contents were measured using a Leco CS 300 (precision of measurement: $\pm 3 \%$ ). Assuming that microbial sulfate reduction is the main degradation process for sedimentary $\mathrm{OM}$ in the Congo fan deposits, we estimated the original content of organic carbon $\left(\mathrm{C}_{\mathrm{org}}{ }^{*}\right)$ according to Littke et al. [1997] following the equation $\mathrm{C}_{\mathrm{org}} *=\mathrm{C}_{\mathrm{org}}+2 \mathrm{~S} *$ $\mathrm{M}_{\mathrm{C}} / \mathrm{M}_{\mathrm{S}}\left(\mathrm{S}=\right.$ measured sulfur content, $\mathrm{M}_{\mathrm{C}}=$ molecular mass of carbon, $\mathrm{M}_{\mathrm{S}}=$ molecular mass of sulfur). The degradation rate of organic carbon is expressed as the ratio of the measured to the estimated original organic carbon contents $\left(\mathrm{C}_{\text {org }} /\right.$ $\left.\mathrm{C}_{\text {org }}{ }^{*}\right)$. This approach provides minimum estimates, taking into consideration that diffusive escape of $\mathrm{H}_{2} \mathrm{~S}$ from the sediment results in reduced pyrite precipitation in situ and thus in lower sulfur contents. Furthermore, additional oxic degradation may play an important role for OM sinking to greater water depths and its contact to oxic bottom water [Hartnett et al., 1998; Schubert et al., 2001]. However, the oxygen exposure time of sedimentary $\mathrm{OM}$ at the Congo deep-sea fan is expected to be relatively short due to high accumulation rates of fine-grained sediment. The total amount of nitrogen was measured using a Heraeus CNS analyzer (precision of measurement: $\pm 3 \%$ ). A set of 23 selected samples from two core sections
Table 1. Refined Age Model for ODP Site 1075 on the Congo Fan Based on the Correlation of TOC Profiles From ODP Sites 1075 and 1077 and on Previous Studies [Dupont et al., 2001]

\begin{tabular}{|c|c|c|}
\hline Depth 1077, mcd & Depth 1075, mcd & Age, ka \\
\hline 1.99 & 1.65 & 9.20 \\
\hline 4.69 & 3.15 & 22.72 \\
\hline 7.99 & 6.65 & 39.64 \\
\hline 9.49 & 8.15 & 47.34 \\
\hline 11.59 & 10.65 & 58.20 \\
\hline 13.99 & 12.05 & 70.61 \\
\hline 15.42 & 13.15 & 78.00 \\
\hline 16.89 & 14.65 & 88.20 \\
\hline 17.99 & 15.65 & 95.84 \\
\hline 19.49 & 16.55 & 105.21 \\
\hline 22.19 & 18.65 & 120.84 \\
\hline 23.99 & 20.05 & 143.15 \\
\hline 26.19 & 21.91 & 172.24 \\
\hline 26.79 & 22.81 & 180.17 \\
\hline 30.19 & 24.31 & 212.55 \\
\hline 31.69 & 25.41 & 222.46 \\
\hline 35.19 & 29.41 & 243.95 \\
\hline 36.29 & 30.91 & 249.83 \\
\hline 38.19 & 31.83 & 259.98 \\
\hline 39.69 & 32.83 & 268.00 \\
\hline 40.37 & 33.33 & 271.28 \\
\hline 46.37 & 35.33 & 300.17 \\
\hline 48.67 & 36.83 & 311.25 \\
\hline 51.07 & 39.23 & 322.81 \\
\hline 56.75 & 43.25 & 362.38 \\
\hline 58.65 & 45.25 & 383.01 \\
\hline 60.95 & 47.35 & 394.62 \\
\hline 62.49 & 48.25 & 402.39 \\
\hline 65.79 & 51.71 & 419.04 \\
\hline 67.66 & 52.71 & 440.01 \\
\hline 68.15 & 52.91 & 445.85 \\
\hline 68.50 & 53.21 & 450.02 \\
\hline 68.95 & 54.01 & 454.75 \\
\hline 69.87 & 54.74 & 462.80 \\
\hline 70.25 & 54.94 & 466.13 \\
\hline 71.17 & 55.64 & 474.17 \\
\hline 73.95 & 56.58 & 495.26 \\
\hline 75.65 & 57.58 & 507.37 \\
\hline 77.31 & 58.08 & 519.21 \\
\hline 78.43 & 59.58 & 527.19 \\
\hline 79.63 & 61.01 & 535.74 \\
\hline 82.93 & 64.05 & 558.31 \\
\hline 85.23 & 65.05 & 573.01 \\
\hline 87.83 & 67.10 & 589.62 \\
\hline 90.23 & 69.14 & 604.96 \\
\hline 91.23 & 69.64 & 611.35 \\
\hline 92.53 & 70.68 & 619.84 \\
\hline 93.63 & 71.73 & 627.32 \\
\hline 96.63 & 74.19 & 647.11 \\
\hline 98.43 & 75.69 & 658.99 \\
\hline 99.03 & 76.29 & 662.95 \\
\hline 101.43 & 77.83 & 678.78 \\
\hline 103.33 & 78.73 & 694.92 \\
\hline 104.83 & 80.27 & 726.12 \\
\hline 106.33 & 81.77 & 741.56 \\
\hline 107.77 & 82.87 & 759.86 \\
\hline 109.27 & 84.53 & 773.89 \\
\hline
\end{tabular}


Table 1. (continued)

\begin{tabular}{ccc}
\hline Depth 1077, mcd & Depth 1075, mcd & Age, ka \\
\hline 110.37 & 85.50 & 777.86 \\
112.27 & 86.50 & 786.55 \\
115.67 & 89.73 & 825.91 \\
117.27 & 91.28 & 843.77 \\
118.37 & 92.78 & 853.68 \\
119.17 & 93.28 & 863.72 \\
119.87 & 94.65 & 873.84 \\
120.97 & 95.15 & 883.94 \\
122.17 & 95.65 & 894.96 \\
122.87 & 96.51 & 901.39 \\
123.27 & 97.01 & 905.06 \\
123.67 & 97.33 & 908.73 \\
125.17 & 98.33 & 922.23 \\
126.77 & 99.73 & 936.18 \\
127.87 & 100.65 & 945.78 \\
128.67 & 101.05 & 952.75 \\
130.77 & 102.53 & 971.06 \\
132.27 & 103.53 & 984.14 \\
136.47 & 108.33 & 1020.77 \\
140.48 & 111.29 & 1053.56 \\
146.35 & 118.09 & 1101.00 \\
150.45 & 122.84 & 1132.00 \\
152.06 & 124.71 & 1146.01 \\
158.15 & 129.76 & 1199.01 \\
\hline
\end{tabular}

${ }^{\mathrm{a}} \mathrm{mcd}=$ meters composite depth.

(213-330 ka, 519-585 ka) was examined for inorganic nitrogen contents. The samples were treated with a solution of $\mathrm{KOBr}-\mathrm{KOH}$ to convert all organic bound nitrogen into $\mathrm{N}_{2}$ following the method of Silva and Bremner [1966]. The stable isotopic composition of bulk sedimentary organic carbon ( ${ }^{13} \mathrm{C}_{\text {org }}$ versus VPDB) was measured using a Heraeus Elemental Analyzer combined with a Finnigan MAT Delta S mass spectrometer (precision of the measurements: $\pm 0.2 \%$ ). Kerogen was classified according to Espitalie et al. [1977] using the Rock-Eval II device at the Research Center Jülich [precision of measurement for hydrocarbon peaks S1, S2, and carbon dioxide peak S3: $\pm 5 \%$; for $\mathrm{T}_{\max }: \pm 1{ }^{\circ} \mathrm{C}$; Espitalié et al., 1985]. The yields of hydrocarbons and $\mathrm{CO}_{2}$ were calculated from FID and TCD responses, respectively, by means of a gas chromatographic integration system (VAX-Multichrom 2.2). Hydrocarbons and hydrocarbon-like components that are generated from the kerogen fraction of the bulk sediment were quantitatively detected within the S2 temperature window. Holtvoeth et al. [2001] observed that kerogen of samples from ODP Site 1075 generates hydrocarbons in two temperature sub-windows resulting in a distinct double peak of the bulk S2 peak. Variations in the relative proportions of hydrocarbons are generated from two principally different organic sources, i.e., low-mature and high-mature OM. Quantification of the S2 partial peak areas $\left(\mathrm{S} 2_{\mathrm{lm}} / \mathrm{S} 2_{\mathrm{hm}}\right)$ resulted in the establishment of a new proxy for bulk OM reactivity, the "lowmature/high-mature ratio" ( $\mathrm{lm} / \mathrm{hm}$ ratio). This proxy was applied to Late Quaternary sections of ODP Site 1075 to infer climate-driven fluctuations in reactivity of bulk sedimentary OM (Figure 3). Though there are certainly differences in OM reactivity within the two major groups of low-mature and high-mature OM (e.g., POM compared to marine $\mathrm{OM}$ in the low-mature fraction) further differentiation of their individual reactivity is not feasible using a standard Rock-Eval temperature program (heating rate: $25^{\circ} \mathrm{C} / \mathrm{min}$ from $300^{\circ} \mathrm{C}$ to $550^{\circ} \mathrm{C}$ terminal temperature).

[10] Organic petrological observations were performed using a Zeiss Axiophot. Bulk sediment samples were embedded in a low-viscosity resin, then ground and polished using a Logitech PM 2A (for details see Wagner [1998, 1999]). The organic particles were sorted by grain size in 5 classes: $<2 \mu \mathrm{m}, 2-5 \mu \mathrm{m}, 5-10 \mu \mathrm{m}, 10-20 \mu \mathrm{m}$, and $>20 \mu \mathrm{m}$. For the calculation of inertinite/vitrinite ratios (I/V) only particles larger $5 \mu \mathrm{m}$ were used, as the determination of these maceral groups is often problematic for very small particles.

[11] 49 samples from three core sections (A: 150 to $85 \mathrm{ka}, \mathrm{B}: 270-210 \mathrm{ka}$, and C: 540-340 ka, see Figure 3) were selected for terrigenous biomarker studies (analysis of lignin oxidation products). Sections A and B both include transitions from glacial to interglacial climate stages (OIS 8-7, $6-5)$ at relatively high amplitudes of the insolation record and were therefore chosen for more detailed investigation. The third section $\mathrm{C}$ was sampled at lower time resolution from an interval with lower amplitudes of insolation to provide additional data for cross-relations. The analytical procedure (CuOoxidation) was carried out according to Goñi and Hedges [1992]. The extracted lignin phenols were analysed using a Hewlett Packard 6890 Series GC system. Two parallel capillary columns (J \& W Scientific $\mathrm{db} 1$ and $\mathrm{db} 1701 ; 30 \mathrm{~m} * 0.25 \mathrm{~mm}$, 


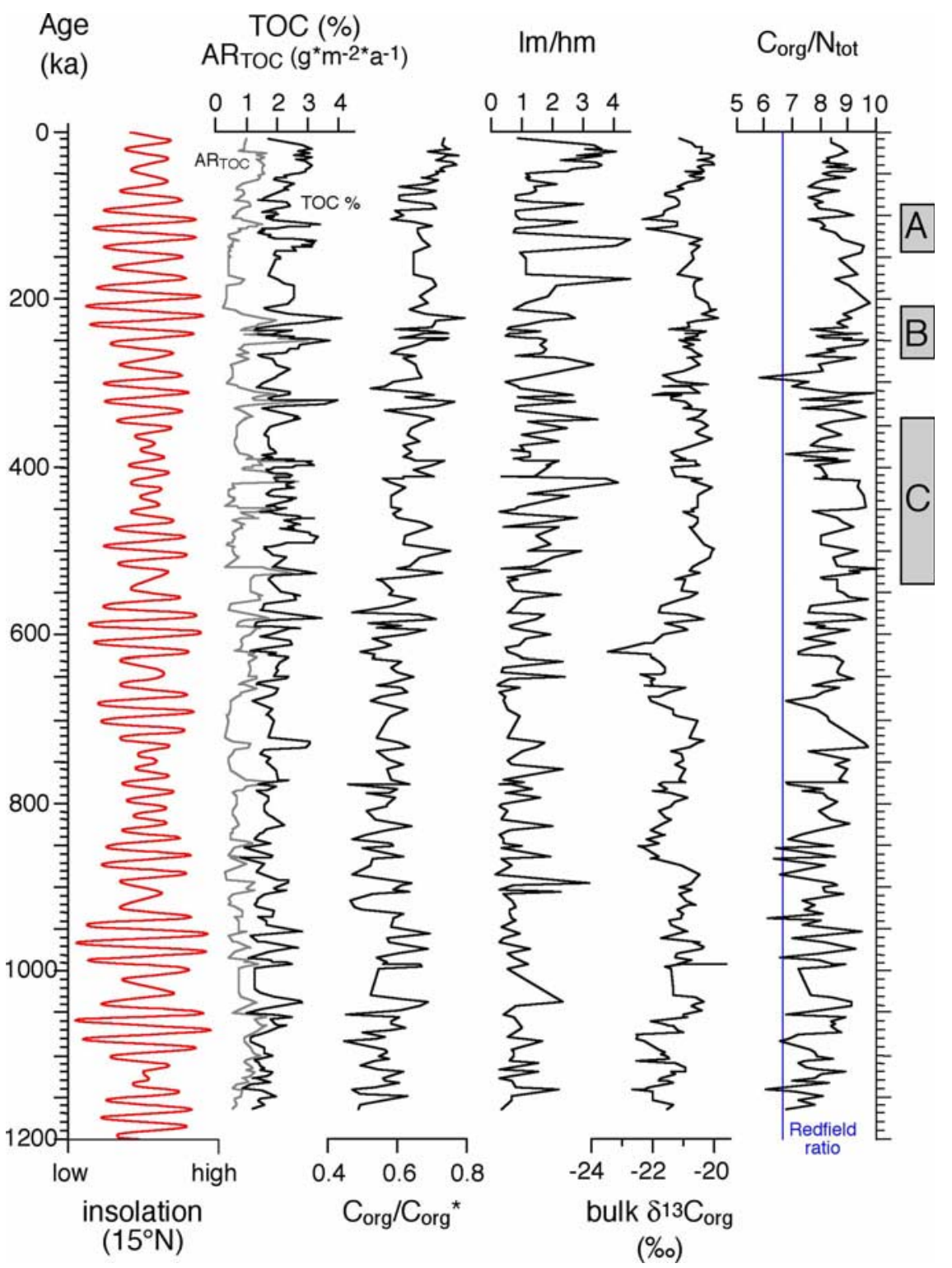

Figure 3. Records from elemental analysis (TOC, $\mathrm{C}_{\text {org }} / \mathrm{N}_{\text {tot }}$ ), mass spectrometry (bulk $\delta^{13} \mathrm{C}_{\text {org }}$ ), and Rock-Eval pyrolysis $(\mathrm{lm} / \mathrm{hm})$ of Late Quaternary sections from ODP Site 1075 compared to the record of insolation at $15^{\circ} \mathrm{N}$ [from Holtvoeth et al., 2001]. $\mathrm{C}_{\mathrm{org}} / \mathrm{C}_{\mathrm{org}}$ * shows the (minimum) degradation rate of bulk organic carbon, estimated based on microbial sulfate reduction only. Note that the $\mathrm{C}_{\mathrm{org}} / \mathrm{C}_{\text {org }} *$ record differs from the record of $\mathrm{C}_{\text {org }} / \mathrm{S}_{\text {tot }}$ ratios (range 0.6 to 2.9$)$ only by its amplitudes as both parameters are strongly exponentially correlated $\left(\mathrm{r}_{\exp }^{2}=1\right)$.

$0.25 \mu \mathrm{m}$ film) were used for chromatography. Opsahl and Benner [1995] demonstrate that the ester-bound cinnamyl phenols, $p$-coumaric acid and ferulic acid, are the lignin components most susceptible to degradation processes. To overcome that problem they suggested the use of only the sum of the six lignin-derived syringyl and vanillyl phenols $\left(\Lambda_{6}\right)$ instead of the "classical" $\Lambda$ that sums syringyl, vanillyl, and cinnamyl phenols $\left(\Lambda_{8}\right)$.
Indeed, the determination of peak areas turned out to be problematic for the ester-bound components because they were strongly affected by co-elution effects. The uncertainty of assignment of the ferulic acid signal results in a mean deviation of $16 \%$ for the ratio of cinnamyl to vanillyl phenols $(\mathrm{C} / \mathrm{V})$. However, $\Lambda_{6}$ and $\Lambda_{8}$ in this study show a very good correlation $\left(\mathrm{r}^{2}=0.99\right)$ indicating that coumaric and ferulic acid, forming the cinnamyl 
Table 2. Range, Mean Value, and Mean Deviation of Parameters From Lignin Oxidation ${ }^{\mathrm{a}}$

\begin{tabular}{ccccccc}
\hline & $\Lambda_{8}, \mathrm{mg} / \mathrm{gTOC}$ & $\Lambda_{6}, \mathrm{mg} / \mathrm{gTOC}$ & $\mathrm{S} / \mathrm{V}$ & $\mathrm{C} / \mathrm{V}$ & $(\mathrm{Ad} / \mathrm{Al})_{\mathrm{V}}$ & $(\mathrm{Ad} / \mathrm{Al})_{\mathrm{S}}$ \\
\hline Range & $0.066-0.373$ & $0.057-0.316$ & $0.47-1.38$ & $0.15-0.39$ & $0.47-1.74$ & $0.26-1.94$ \\
Mean value & 0.151 & 0.130 & 0.87 & 0.28 & 0.72 & 0.46 \\
Mean deviation & $16 \%$ & $14 \%$ & $7 \%$ & $13 \%$ & $17 \%$ & $14 \%$ \\
\hline
\end{tabular}

\footnotetext{
${ }^{\mathrm{a}} \mathrm{S}=$ syringaldehyde + acetosyringone + syringic acid, $\mathrm{C}=p$-coumaric acid + ferulic acid, $\mathrm{V}=$ vanillin + acetovanillone + vanillic acid $[\mathrm{mg} /$ $100 \mathrm{mgTOC}] ; \Lambda_{8}=\mathrm{S}+\mathrm{C}+\mathrm{V}, \Lambda_{6}=\mathrm{S}+\mathrm{V} ;(\mathrm{Ad} / \mathrm{Al})_{\mathrm{V}}=$ vanillic acid/vanillin, $(\mathrm{Ad} / \mathrm{Al})_{\mathrm{S}}=$ syringic acid $/$ syringaldehyde.
}

group, are not more strongly degraded after deposition than other lignin components. The lignin data presented in this study therefore are given as $\Lambda_{8}$ and as the established ratios of individual groups $\mathrm{C} / \mathrm{V}, \mathrm{S} / \mathrm{V},(\mathrm{Ad} / \mathrm{Al})_{\mathrm{v}}$, and $(\mathrm{Ad} / \mathrm{Al})_{\mathrm{s}}$. Duplicate $\mathrm{CuO}$ oxidation and extraction runs were performed for 16 samples and the obtained lignin phenols were analysed in different GC-runs. The resulting mean deviations of the lignin parameters range from $7 \%$ for $\Lambda_{8}$, to $17 \%$ for $(\mathrm{Ad} / \mathrm{Al})_{\mathrm{V}}$ (Table 2$)$. Regarding primary differences in lignin yields of the various terrigenous organic fractions (POM, soil $\mathrm{OM}, \mathrm{BC}$; compare Figure 1) we emphasize that $\Lambda_{8}$ is not representative for the total terrigenous $\mathrm{OM}$ fraction and therefore can hardly be used to estimate marine versus terrigenous fractions of the bulk OM. Instead, variations in concentration and accumulation of lignin result from a combination of various processes, in principle changing riverine supply of terrigenous $\mathrm{OM}$ and alternating relative shares of the lignin sources. All geochemical data presented in this study are available at http:// www.pangaea.de.

\section{Results}

[12] At ODP site 1075, late Quaternary sediments of the Congo deep-sea fan contain 0.8 to $4.2 \%$ total organic carbon (average TOC is $2.1 \%$, Figure 3 ) [Holtvoeth et al., 2001]. Degradation rates $\left(\mathrm{C}_{\mathrm{org}} /\right.$ $\mathrm{C}_{\text {org }}{ }^{*}$ ) indicate that (at least) $25-55 \%$ of the organic carbon is mineralized under sulfate reducing conditions. The ratios of hydrocarbons released from low-mature (high-reactive) and high-mature (low-reactive) $\mathrm{OM}(\mathrm{lm} / \mathrm{hm}$ ratio) range from 0.2 to 4.5. The latter parameter was initially established as new bulk OM-reactivity proxy that bases on the relative proportions of hydrocarbon yields from low-mature (reactive) and high-mature (lessreactive) organic fractions obtained in the $\mathrm{S} 2$ temperature window during Rock-Eval pyrolysis (see Holtvoeth et al. [2001] for more details). Notably, there is a gradual decrease in baseline $\mathrm{lm} / \mathrm{hm}$ values from about 1.0 at the core top to about 0.2 at $650 \mathrm{ka}$ suggesting a progressive relative enrichment of a high-mature (more stable) organic compound with increasing depth. Bulk OM reactivity $(\mathrm{lm} / \mathrm{hm}$ ratio) and TOC generally co-vary $\left(\mathrm{r}^{2}=0.4\right)$ revealing the best correlation in the upper $20-30 \mathrm{~m}$ of the record $\left(125-0 \mathrm{ka}: \mathrm{r}^{2}=\right.$ $0.93,250-0 \mathrm{ka}: \mathrm{r}^{2}=0.70$, respectively).

[13] Figure 4 illustrates the relationship of TOC and the amount of hydrocarbons generated from

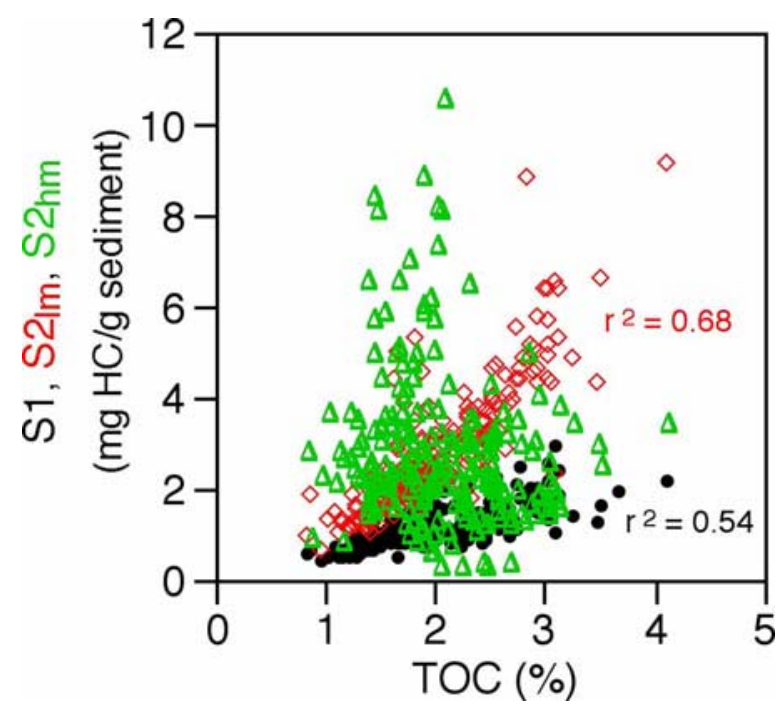

Figure 4. Hydrocarbon (HC) generation of ODP Site 1075 samples represented by $\mathrm{S} 1$ (black dots), $\mathrm{S} 2_{1 \mathrm{~m}}$ (open diamonds), and $\mathrm{S} 2 \mathrm{hm}$ (open triangles) yields relative to TOC contents. TOC is mainly shaped by low-reactive $\mathrm{OM}$ generating $\mathrm{HC}$ 's in the $\mathrm{S} 1$ and $\mathrm{S} 2{ }_{1 \mathrm{~m}}$ temperature windows. Samples with low TOC are dominated by the relative proportion of high-mature OM. Notably, this fraction generates astounding high $\mathrm{HC}$ quantities $\left(\mathrm{S} 2_{\mathrm{hm}}\right)$ that are comparable or even exceed those of low-mature $\mathrm{OM}$. The HC generation capacity of the high-mature organic fraction supports the assumption that a variety of continental sources contributes to that fraction. 
immature (S1), low-mature ( $\left.\mathrm{S} 2_{1 \mathrm{~m}}\right)$, and highmature $\mathrm{OM}\left(\mathrm{S} 2_{\mathrm{hm}}\right)$. The data support the conclusion that variations in bulk TOC are mainly determined by the concentration of labile $\mathrm{OM}$ (represented by $\mathrm{HC}$ from $\mathrm{S} 1$ and $\mathrm{S} 2_{1 \mathrm{~m}}$ ). Accordingly, progressive degradation of low-mature OM results in decreasing TOC contents and relative enrichment of high-mature OM. Notably, the highest amounts of hydrocarbons are not released from the low-mature organic fraction at highest TOC concentration but instead are recognized in samples with less than 2\% TOC (background level at Site 1075) and within the high-mature fraction. This observation is opposite to what may be expected, however, it confirms that the fraction of high-mature OM is not inert at all. We infer highmature OM in Congo fan deposits is composed of a variety of terrigenous organic sources. These sources may include contribution of reworked peat/soil/ swamp OM and inert organic carbon (charcoal or dead carbon). Peak hydrocarbon generation in low TOC samples must be related to the presence of OM from these sources.

[14] Bulk $\delta^{13} \mathrm{C}_{\text {org }}$ values range from -19 to $-23.5 \%$ (Figure 3) [Holtvoeth et al., 2001]. Application of a conventional binary mixing equation for marine and $\mathrm{C}_{3}$ terrigenous $\mathrm{OM}$ $(-18 \%,-27 \%$, respectively) suggests that between $18 \%$ and $61 \%$ (average $35 \%$ ) of the bulk $\mathrm{OM}$ is continental in origin assuming only the presence of a single isotopically light terrigenous organic fraction $\left(\mathrm{C}_{3}\right.$ plant remains). TOC contents correlate well with calculated amounts of the isotopically heavy end-member fraction (marine/ bacterial $\mathrm{OM}, \mathrm{C}_{4}$ plant matter, $\mathrm{r}^{2}=0.94$ ) but not with the ${ }^{13} \mathrm{C}$-depleted one $\left(r^{2}=0.27\right)$. Highest amounts of isotopically light terrigenous $\mathrm{OM}$ $(>40 \%)$ occur only in samples with less than $2.5 \%$ TOC, whereas samples with higher TOC $(>2.5 \%)$ typically imply less than $30 \%$ light terrigenous $\mathrm{OM}$.

[15] $\mathrm{C}_{\text {org }} / \mathrm{N}_{\text {tot }}$ ratios range from 5.8 to 10.1 (8.3 on average) over the stratigraphic record [Holtvoeth et al., 2001]. Organic carbon and total nitrogen yields are strongly correlated $\left(\mathrm{r}^{2}=0.86\right.$, Figure 5$)$. The intercept point of the regression line for $0 \%$ TOC at $0.06 \% \mathrm{~N}_{\text {tot }}$ provides evidence for additional

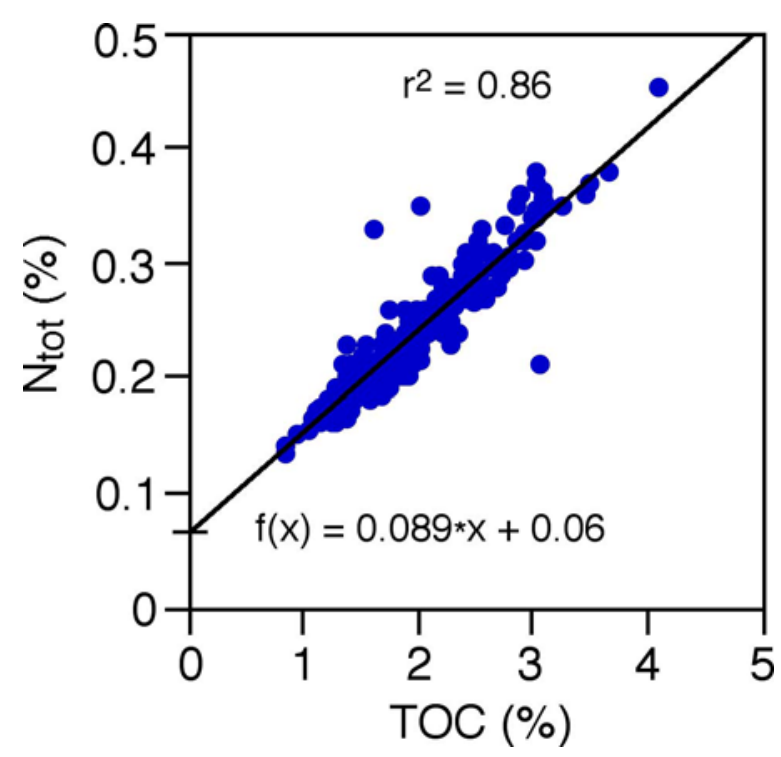

Figure 5. Relation of total organic carbon (TOC) and total nitrogen $\left(\mathrm{N}_{\text {tot }}\right)$ in late Quaternary sections of ODP Site 1075; intercept of regression at $0,06 \% \mathrm{~N}_{\text {tot }}$ for zero TOC suggests that part of the total nitrogen is inorganic.

contribution of nitrogen from an inorganic source such as ammonium bound to clay minerals. Investigation of samples from sections $\mathrm{B}$ and $\mathrm{C}$ confirm these implications as they reveal that $8 \%$ to $16 \%$ of the total nitrogen content is inorganic. TOC and organic nitrogen show an excellent correlation $\left(\mathrm{r}^{2}=\right.$ 0.97 ) for all samples. $\mathrm{C}_{\text {org }} / \mathrm{N}_{\text {org }}$ ratios range from 8.1 to 11.1 (average 9.7) and thus are 14\% higher than the ratios of TOC and total nitrogen. Ratios of inorganic to organic nitrogen $\left(\mathrm{N}_{\text {inorg }} / \mathrm{N}_{\text {org }}\right)$ slightly increase from 0.14 to 0.16 with increasing depth. Extrapolation of this trend would result in approximately $20 \% \mathrm{~N}_{\text {inorg }}$ of $\mathrm{N}_{\text {tot }}$ at the bottom of the profile. The good correlation of $\mathrm{C}_{\text {org }} / \mathrm{N}_{\text {org }}$ with $\mathrm{C}_{\text {org }} / \mathrm{N}_{\text {tot }}$ ratios $\left(\mathrm{r}^{2}=0.92\right)$, however, justifies the use of total nitrogen contents to detect changes in bulk OM quality and degradation.

[16] Superimposed on short-term fluctuations in primary composition of sedimentary OM long-term trends over the entire Late Quaternary record are observed (Figure 3). Specifically, TOC, $\mathrm{C}_{\text {org }} / \mathrm{C}_{\text {org }}$ *, $\mathrm{lm} / \mathrm{hm}$, and $\mathrm{C}_{\text {org }} / \mathrm{N}_{\text {tot }}$ ratios generally decrease with depth while bulk $\delta^{13} \mathrm{C}_{\text {org }}$ shifts to slightly lighter values. The consistency of these trends has been used to argue for the selective enrichment 

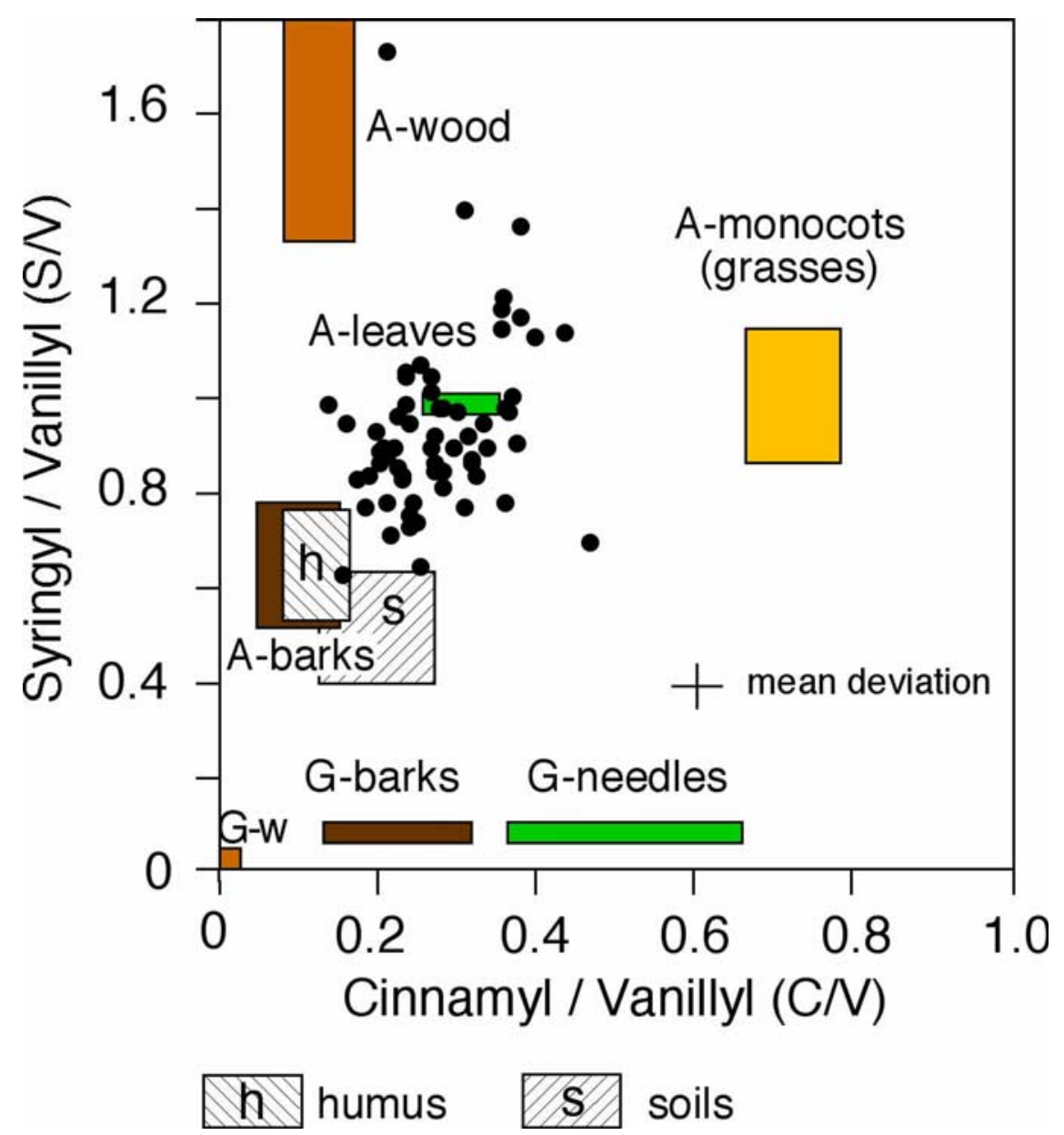

Figure 6. Ratios of specific lignin phenols (S/V, C/V) from lignin chemistry of selected samples from ODP Site 1075. According to Goñi and Hedges [1992] and Farella et al. [2001], terrigenous OM in the sediments of the Congo fan mainly derives from angiosperm leaves and barks, or soil and humus with admixture of angiosperm wood and grass; $\mathrm{V}=$ vanillin + acetovanillone + vanillic acid in $\mathrm{mg} / 100 \mathrm{mg} \mathrm{TOC}, \mathrm{S}=$ syringaldehyde + acetosyringone + syringic acid in $\mathrm{mg} / 100 \mathrm{mg}$ TOC, $\mathrm{C}=p$-coumaric acid + ferulic acid in $\mathrm{mg} / 100 \mathrm{mg} \mathrm{TOC} ; \mathrm{A}=\operatorname{angiosperm}, \mathrm{G}(\mathrm{w})=$ gymnosperm wood.

of a more stable terrigenous organic fraction in response to long-term diagenesis [Holtvoeth et al., 2001].

[17] The $\mathrm{C} / \mathrm{V}$ and $\mathrm{S} / \mathrm{V}$ ratios (cinnamyl/vanillyl, syringyl/vanillyl) from lignin analysis range from 0.15 to 0.47 and from 0.61 to 1.71 , respectively (Figure 6). The projection of these ratios in a general scheme to classify plant tissue (according to Hedges and Mann [1979b], Goñi and Hedges [1992], Farella et al. [2001]) reveals that terrigenous OM in Late Quaternary deposits of the Congo fan mainly originates from non-woody angiosperm tissues with variable admixture of angiosperm wood (mainly barks) and soil or humus OM. Given the geographic and geological context of the Congo catchment area with its extensive rain forest and swamp areas, a preferential admixture of soil OM appears plausible.

\subsection{Relationship of Bulk OM Reactivity, Degradation Rates, and Lignin Phenol Yields}

[18] The relationships of bulk OM reactivity $(\mathrm{lm} /$ $\mathrm{hm}$ ), degradation rates, and lignin phenol yields provide insights on primary differences in the composition of bulk $\mathrm{OM}$ and their corresponding susceptibility to degradation (Figure 7). The distribution of data from the Congo site reveals two 

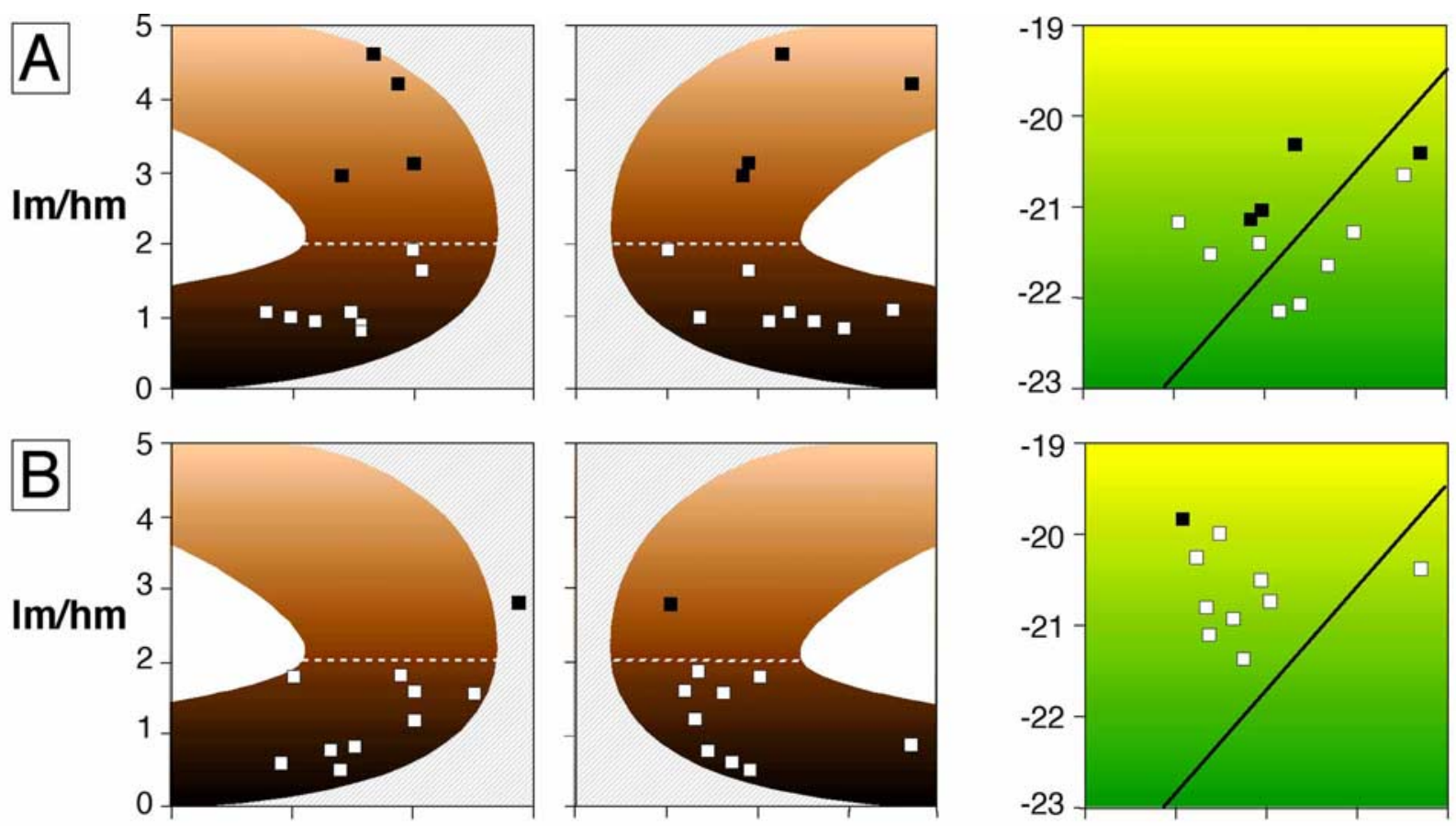

C
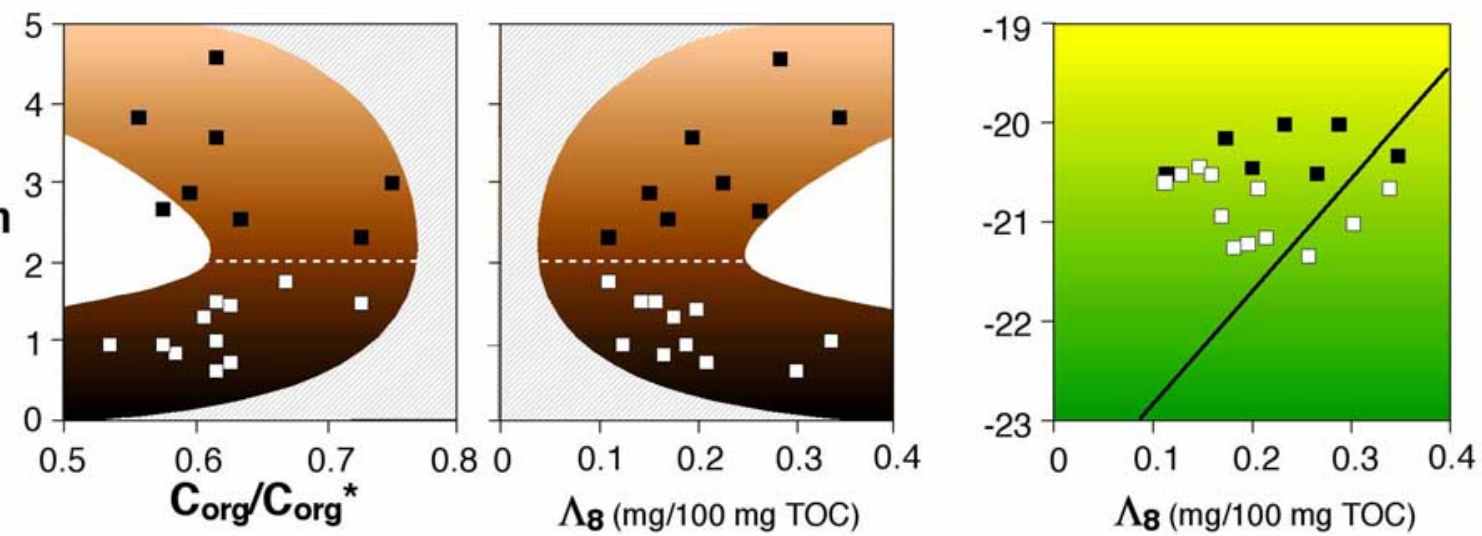

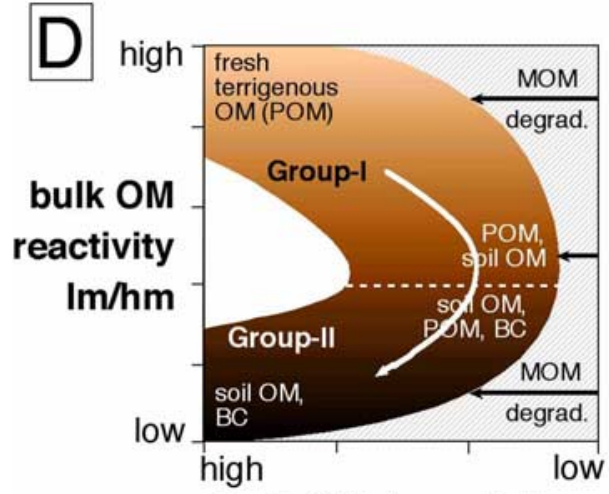

bulk OM degradation
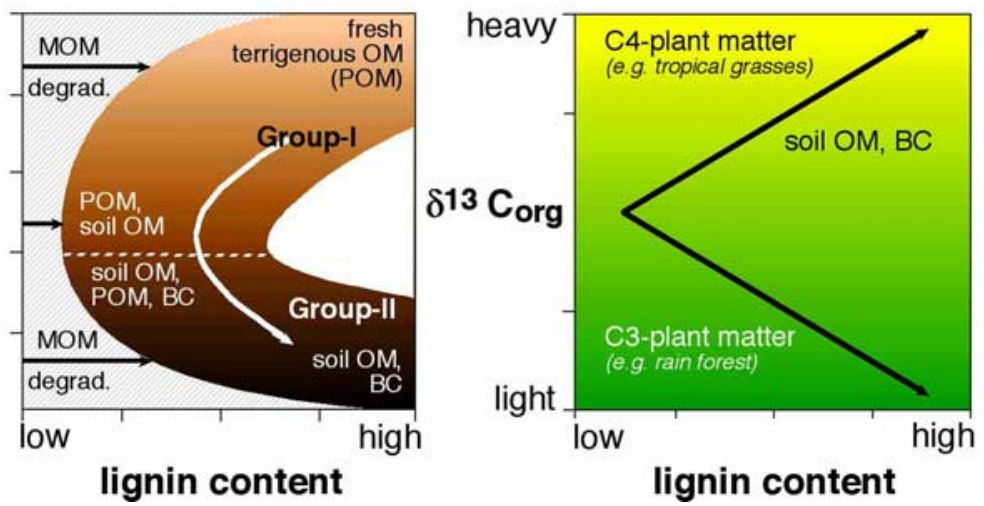
different groups of samples, i.e., Group-I and Group-II. All samples represent residual mixtures of autochthonous (marine/bacterial) OM, fresh particulate terrigenous-derived $\mathrm{OM}(\mathrm{POM})$, and BC-bearing soil OM, the latter components being selectively enriched with diagenesis. Remarkably, there are no samples with low contents of lignin phenols and high ratios of both, $\mathrm{C}_{\text {org }} / \mathrm{C}_{\text {org }}{ }^{*}$ and $\mathrm{lm} / \mathrm{hm}$, a combination that would support a dominance of high-reactive, non-degraded autochthonous OM. This circumstance proposes that a large part of the primary autochthonous OM has already been selectively degraded, and thus does not contribute an important share to the bulk OM in Congo deep-sea fan sediments. Instead, variable fractions of fresh, degraded, and inert terrigenous OM determine the total organic signature. The main source of lignin in G-I samples is reactive POM (tissues directly from plants growing in the Congo catchment area). A decrease in this lignin-rich source goes along with a continuous increase in lignin-poor soil OM resulting a drop in bulk OM reactivity (expressed as $1 \mathrm{~m} / \mathrm{hm}$ ratios) and lignin concentrations. At moderate bulk OM reactivity levels (corresponding to $\mathrm{lm} / \mathrm{hm}$ ratios of about 2), a principle change of the main lignin source from POM to soil OM occurs. This transition leads to a progressive decline of POM while relative proportions of soil $\mathrm{OM}$ increase. Finally, the relative amounts of soil OM in G-II samples with lignin phenol concentrations comparable to those of G-I samples must significantly exceed the proportions of POM in G-I samples given the primarily low lignin yields of soil OM. Most likely, the described change from POM to soil $\mathrm{OM}$ as the main lignin source is accompanied by a relative increase in $\mathrm{BC}$ associated with soil OM that reduces bulk OM reactivity to its minimum.

[19] The results obtained are summarized in a conceptual model (illustration D in Figure 7). It is important to realize that two major processes determine the organic geochemical signature of bulk OM in the Congo deep-sea fan sediments: (1) the change of the primary composition in response to climate variability and (2) microbial degradation of labile (mainly marine) biomass during and after deposition. The model proposes that maximum $\mathrm{C}_{\text {org }} / \mathrm{C}_{\text {org }}$ * ratios are related to conditions of massive supply of labile OM to the sediment, thus to enhanced marine primary productivity stimulated either by elevated upwellingor river-induced nutrient supply. Accordingly, G-I samples (maximum $\mathrm{lm} / \mathrm{hm}$ values, reactive POM) represent periods of minimum soil erosion and supply, likely in response to arid climate conditions in central Africa and reduced fluvial run-off. Enhanced trade intensity during these periods should have fostered primary productivity to produce elevated $\mathrm{C}_{\text {org }} / \mathrm{C}_{\text {org }}$ * ratios in the sedimentary record. In contrast, G-II samples (minimum $1 \mathrm{~m} / \mathrm{hm}$ ratios) document periods of humid climatic conditions. These were associated with massive erosion and supply of soil OM from high-productive rain forest areas in tandem with enhanced fluvial nutrient supply forcing marine primary productivity and flux of labile OM. The transition from wind- to river-induced high-productivity is characterized by minima in marine primary production consequently leading to lowest degradation rates.

Figure 7. (opposite) Relationship of bulk OM degradation $\left(\mathrm{C}_{\mathrm{org}} / \mathrm{C}_{\mathrm{org}}{ }^{*}\right)$ and reactivity $(\mathrm{lm} / \mathrm{hm} \mathrm{index})$, lignin concentration $\left(\Lambda_{8 / 6}\right)$, and bulk carbon isotopic signatures (bulk $\delta^{13} \mathrm{C}_{\mathrm{org}}$ ) in samples from three time intervals of ODP Site 1075 (for assignment of time intervals Figures 7a-7c see Figure 3), and a conceptual model derived from the data (Figure 7d). Accordingly, the main source of lignin in relatively reactive Group-II samples $(\mathrm{lm} / \mathrm{hm}>2)$ is particulate terrigenous OM (POM), whereas lignin derives mainly from degraded soil OM in low-reactive $(\mathrm{lm} / \mathrm{hm}<2)$ Group-II samples. Shaded grey areas represent variable relative proportions of marine OM that have been degraded (MOM degrad. = marine OM degradation, effectiveness illustrated by black arrows) leading to elevated degradation rates (low $\mathrm{C}_{\mathrm{org}} / \mathrm{C}_{\mathrm{org}}{ }^{*}$ values); white arrow indicates progressive change from POM- to soil OM-dominated river load, from upwelling- to river-controlled nutrient supply, respectively (see text for further explanation). In both extreme scenarios, degradation of labile MOM is very effective, only during the transitional stage ( $\mathrm{lm} / \mathrm{hm}$ ratios around 2) degradation and probably also primary production is reduced. Influence of ${ }^{13} \mathrm{C}$-enriched $\mathrm{OM}\left(\mathrm{C}_{4}\right.$ plant matter, $\mathrm{C}_{4}$ soil $\mathrm{OM}, \mathrm{BC}$ ) is indicated by positive correlation of lignin yields with bulk $\delta^{13} \mathrm{C}_{\text {org }}$ for samples either enriched in soil OM or with maximum amounts of POM (presumably from $\mathrm{C}_{4}$ habitats). 
Obviously, the proposed conceptual model of interrelated bulk OM primary composition and degradation on the Congo Fan is intimately linked to the temporal development of environmental conditions and climate, which is discussed below.

[20] The contribution of $\mathrm{C}_{4}$ plant matter, soil $\mathrm{OM}$ from $\mathrm{C}_{4}$ habitats, and $\mathrm{BC}$ adds terrigenous components to the bulk organic pool that may complicate the interpretation of the bulk $\mathrm{OM}$ isotopic signal due to the distinct enrichment of ${ }^{13} \mathrm{C}$ especially in $\mathrm{C}_{4}$ plants $\left(\delta^{13} \mathrm{C}_{\mathrm{org}} \approx-12 \%\right)$ but also in degraded soil $\mathrm{OM}$ and $\mathrm{BC}$. In the absence of a dominant marine organic fraction, $\mathrm{C}_{4}$ plant matter from POM or soil OM as well as $\mathrm{BC}$ may at least be detectable from the bulk isotopic composition. Significant influence of ${ }^{13} \mathrm{C}$-enriched $\mathrm{OM}$ on the bulk $\delta^{13} \mathrm{C}_{\text {org }}$ signal is expected only for samples with highest contents of lignin, i.e., either from reactive POM (Group-I), from soil OM (Group-II), or for samples enriched in BC (Group-II, $\mathrm{lm} / \mathrm{hm} \ll 2$ ). Indeed, the relationship of $\Lambda_{8}$ as a gross indicator of the two principle types of terrigenous OM (POM, soil OM) and bulk $\delta^{13} \mathrm{C}_{\text {org }}$ reveal a positive correlation for the most lignin-rich samples supporting the presence of "fresh" $\mathrm{C}_{4}$ tissue (for $\Lambda_{8}>0.3$, filled symbols right of trend line in Figure 7) and of diagenetically altered, probably $\mathrm{BC}$-containing soil $\mathrm{OM}$ with low $1 \mathrm{~m} / \mathrm{hm}$ values $\left(\Lambda_{8}>\sim 0.2\right.$, open symbols right of trend-line in Figure 7). Over the entire Late Quaternary record of site 1075 samples with $1 \mathrm{~m} / \mathrm{hm}$ values $<1.5$ (Group-II) tend to have slightly lower bulk $\delta{ }^{13} \mathrm{C}_{\text {org }}$ values $(-21.3 \%$ on average) than Group-I samples (-20.5\%) with $\mathrm{lm} / \mathrm{hm}$ values $>2.5$ probably indicating that soil $\mathrm{OM}$ originates mainly from $\mathrm{C}_{3}$ habitats while POM contains an enhanced proportion of $\mathrm{C}_{4}$ plant remains.

[21] Results from organic petrological investigations strongly favour an important supply of fine-grained soil $\mathrm{OM}$ as almost $90 \%$ of the non-fluorescent (terrigenous) macerals are smaller than $10 \mu \mathrm{m}, 67 \%$ even smaller than $5 \mu \mathrm{m}$. Though qualitative observations reveal the existence of terrigenous particles with distinct differences in the degree of oxidation (vitrinites and inertinites) a reliable quantification of these two terrigenous maceral groups is problematic due to the mean particle size. A more reliable estimation for the ratio of inertinite and vitrinite $(\mathrm{I} / \mathrm{V})$ is possible for terrigenous particles larger than $5 \mu \mathrm{m}$. Accordingly, I/V ratios range from 0.24 to 1.0 (av. 0.56) indicating a predominance of moderately oxidized particles. The average $\mathrm{I} / \mathrm{V}$ ratio is clearly lower for particles larger $10 \mu \mathrm{m}(\mathrm{I} / \mathrm{V}=$ 0.19 ) thus suggesting an increasing degree of oxidation with decreasing particle size. Indeed, the I/V ratio for particles smaller $5 \mu \mathrm{m}$ appears to be drastically increased (av. $\mathrm{I} / \mathrm{V}=0.95$ ). However, this estimation is questionable for the reason mentioned above. Notably, high-fluorescent marine alginites and amorphous organic matter are rare in the Congo fan sediments. Instead, high-fluorescent particles of less than $2 \mu \mathrm{m}$ in size comprise almost $50 \%$ of the observed marine and probably bacterial biomass. On the basis of organic petrology about $73 \%$ on average of the bulk $\mathrm{OM}$ is terrigenous in origin, with minimum and maximum values of $83 \%$ and $61 \%$, respectively.

[22] To place the observed relationships of OM composition, degradation and reactivity in a stratigraphic and environmental context and to assess to which extend specific groups of lignin were selectively affected by degradation processes we next present the three proxy records together with other bulk geochemical and lignin-specific data for the two time slices with highest resolution (i.e., OIS 8 to 7 and OIS 6 to 5, Figures 8 and 9).

\subsection{Temporal and Environmental Context of OM Variations (OIS 8 to 7 and OIS 6 to 5 )}

[23] During both time intervals the TOC record as well as the ratio of low-reactive to high-reactive $\mathrm{OM}(\mathrm{lm} / \mathrm{hm}$ ratio) run parallel (except for one single data point at $240 \mathrm{ka}$, Figure 8) and reveal a close relation to the precessional-forced record of insolation. This positive relationship already suggests a link between OM composition and abundance and climate-related depositional processes. Characteristically, maxima in TOC and bulk OM reactivity post-date insolation minima by about $3-$ 


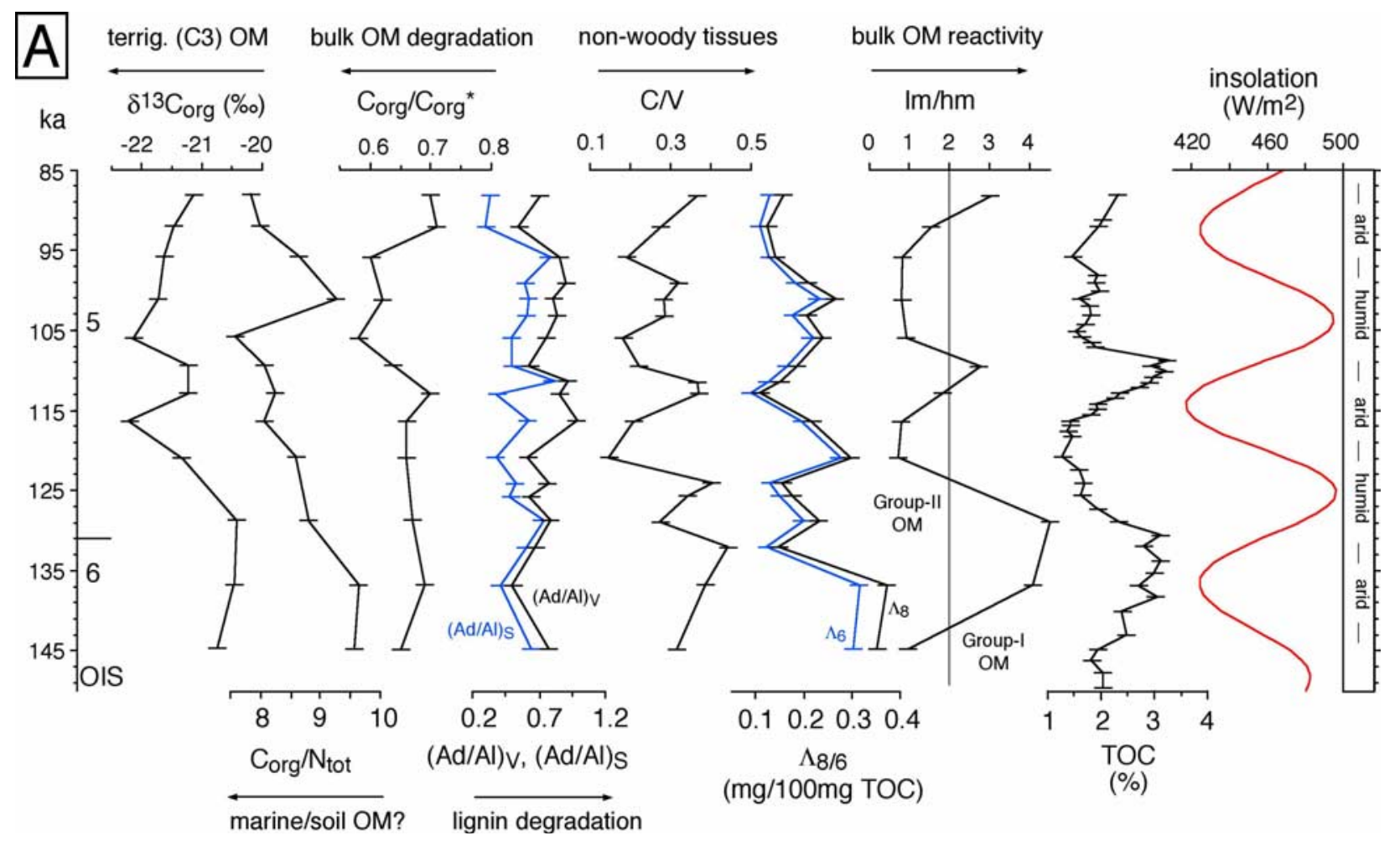

Figure 8. Time series of bulk organic-geochemical and biomarker records from time section A (147-85 ka, OIS $6-5$ ) at ODP Site 1075 compared to the insolation record at $15^{\circ} \mathrm{N}$. Note close relation of TOC and $\mathrm{lm} / \mathrm{hm}$ records to insolation with maxima in reactive (marine and terrigenous) OM occurring $2-5$ kyrs following insolation minima due to depressed supply of low-reactive soil OM during arid African climates. The distinct relation of $\mathrm{C} / \mathrm{V}$ and lignin yields $\left(\Lambda_{8 / 6}\right)$ suggests that elevated concentrations of lignin are attributable to enhanced amounts of either woody plant tissue or soil OM.

5 kyrs (Figures 8 and 9). This time delay is a robust feature of the entire stratigraphic interval investigated as has been shown for the general phase relation between insolation and TOC content and accumulation over the past 1.2 million years [Wagner et al., 2003, Figure 10]. Determining the specific time interval to the next insolation maximum for each sample and assigning each sample to 2-kyrs-time-windows as part of an idealized insolation cycle of $20 \mathrm{kyrs}$, the data from Congo Site 1075 clearly reveals a systematic coupling of bulk OM sedimentation or preservation with insolation. With increasing depth, however, the correlation fades-out due to long-term diagenesis and potential changes in the prominent orbital frequencies (e.g., associated with the mid-Pleistocene transition). The synchrony of $1 \mathrm{~m} / \mathrm{hm}$ with TOC indicates that reactive $\mathrm{OM}$ dominates slightly following insolation minima, while the relative share of more stable OM is preferentially linked to periods of highest or decreasing insolation.

[24] The detailed records from lignin analysis $\left(\Lambda_{8 / 6}\right.$ and $\mathrm{X} / \mathrm{s}$ ) for OIS 6-5 (Figure 8) and OIS 8-7 (Figure 9) do not follow this systematic pattern, but they reveal some significant differences between the two time slices. Whereas $\Lambda_{8 / 6}$ shows no clear relation to TOC during OIS $6-5$, it is negatively correlated with TOC during OIS 7-8. For both time slices a distinct negative covariation of $\Lambda_{8 / 6}$ with $\mathrm{C} / \mathrm{V}$ is also recognizable suggesting that terrigenous OM contains enhanced proportions of non-woody plant tissues and probably less soil $\mathrm{OM}$ in samples with low lignin concentrations compared to their lignin-rich counterparts.

[25] The profiles of bulk OM degradation $\left(\mathrm{C}_{\text {org }} /\right.$ $\mathrm{C}_{\text {org }}{ }^{*}$ ) imply almost constant preservation during 


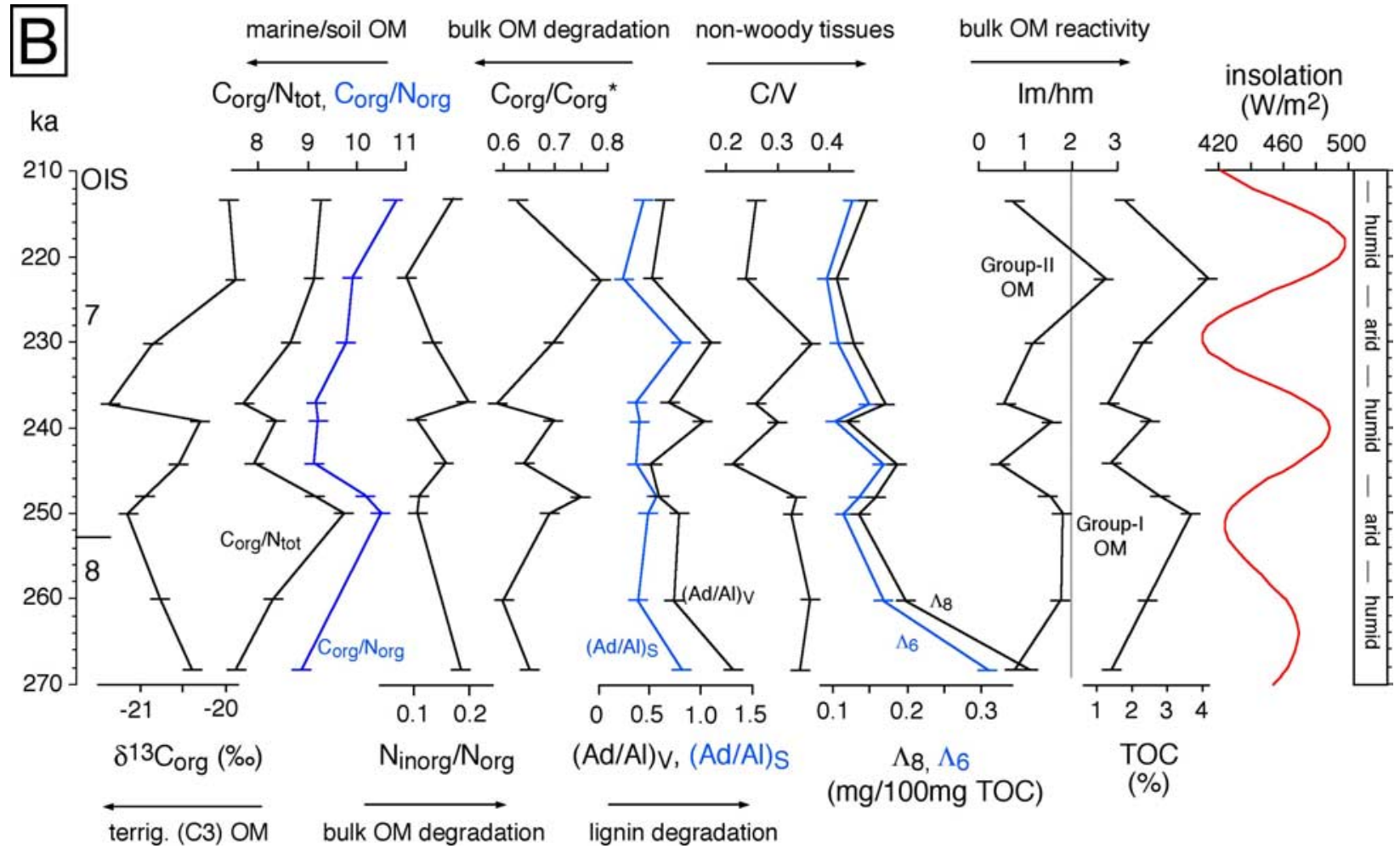

Figure 9. Time series of bulk organic-geochemical and biomarker records from time section B (270-210 ka, OIS $8-7$ ) at ODP Site 1075 compared to the insolation record at $15^{\circ} \mathrm{N}$. Almost all samples belong to Group-II samples. At least during the interglacial stage (OIS 7) the consistency of all parameters suggests that soil $\mathrm{OM}$ from $\mathrm{C}_{3}$ habitats is a major terrigenous fraction that dilutes reactive marine OM and thus determines bulk OM reactivity, $\mathrm{C}_{\text {org }} / \mathrm{N}_{\text {tot }}$ and $\mathrm{C}_{\text {org }} /$ $\mathrm{N}_{\text {org }}$ ratios, as well as bulk $\delta^{13} \mathrm{C}_{\text {org }}$. The highest relative enrichment of soil OM is indicated at 244 and $237 \mathrm{ka}$ whereas enhanced supply of soil OM from former $\mathrm{C}_{4}$ habitats may be deduced from heavier bulk $\delta^{13} \mathrm{C}_{\text {org }}$ around $244 \mathrm{ka}$.

OIS 6 and parts of OIS 5 followed by slightly elevated indices between about 110-90 ka (covering about one insolation cycle) (Figure 8). In the older interval (Figure 9), bulk OM degradation is in the same range ( 0.6 to 0.8 ) but more variable through time. Poorer preservation $\left(\mathrm{C}_{\text {org }} / \mathrm{C}_{\text {org }}\right.$ * below 0.6$)$ is indicated close to the insolation maxima at about $237 \mathrm{ka}$. The corresponding lignin-specific degradation index $(\mathrm{Ad} / \mathrm{Al})_{\mathrm{V} / \mathrm{S}}$ is generally more variable than bulk OM degradation (ranges between 0.26 and 1.3 for OIS $6-5$ and OIS 8-7, respectively) and suggests that degradation of bulk and terrigenous $\mathrm{OM}$ is not necessarily synchronous and coupled, which may be expected in continental margin sediments where only the more residual organic fraction is left for further degradation.

[26] The ancillary records of $\mathrm{C}_{\text {org }} / \mathrm{N}_{\text {tot }}$ and $\mathrm{N}_{\text {inorg }} /$ $\mathrm{N}_{\text {org }}$ (the latter determined for OIS 8-7 only) do not show any clear relation to any of the parame- ters presented, except for OIS 7. There, $\mathrm{N}_{\text {inorg }} / \mathrm{N}_{\text {org }}$ closely follows the bulk OM degradation rate indicating that carbon-nitrogen relationships reflect degradation (i.e., fixation of released ammonium in clay minerals) rather than qualitative changes in the OM. Elevated $\mathrm{N}_{\text {inorg }} / \mathrm{N}_{\text {org }}$ ratios, on the other hand, may also support the presence of ammonium-rich soil material. Enhanced $\mathrm{C}_{\text {org }} / \mathrm{N}_{\text {tot }}$ ratios of almost 10 are observed at $101 \mathrm{ka}$ (OIS 5) or at $250 \mathrm{ka}$ (OIS $8 / 7$ ), and may also be attributed to enhanced proportions of $\mathrm{BC}$, as this component is typically depleted in nitrogen.

[27] The bulk $\delta^{13} \mathrm{C}_{\text {org }}$ signatures are about $0.5-$ $1.5 \%$ enhanced in glacial stage 6 (about $-20.5 \%$ ) compared to interglacial stage 5 ( -21 to $-22 \%$ ) indicating slightly higher relative proportions of marine $\mathrm{OM}$ or a greater admixture of $\mathrm{C}_{4}$-plant matter during glacial conditions (Figure 8). In the older interval (OIS 8-7) the isotopic ratios co-vary 


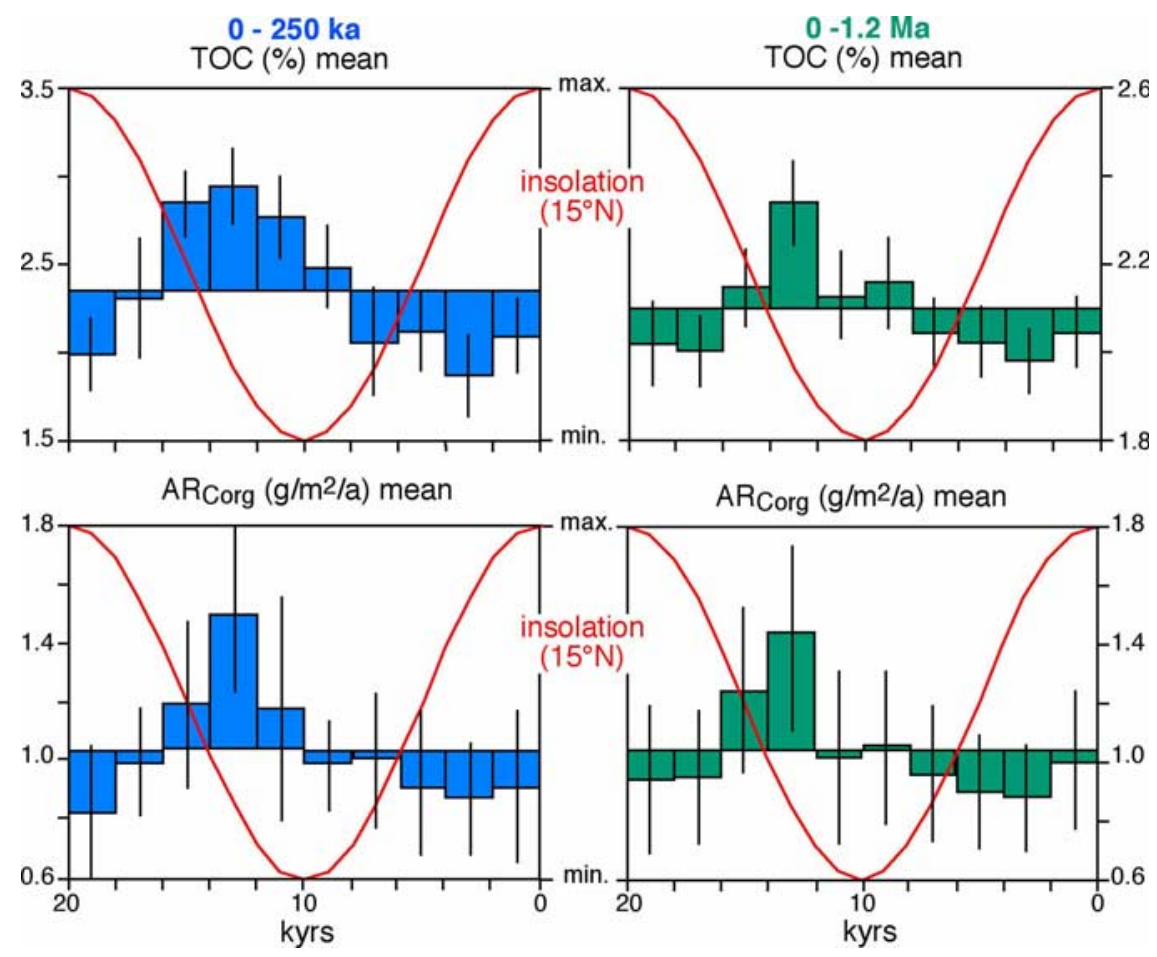

Figure 10. Mean values of TOC contents and accumulation rates in $2 \mathrm{kyr}$ time increments of an idealized insolation cycle ( 10 classes comprising $20 \mathrm{kyrs}$ ) displayed for samples of the upper section of ODP Site 1075 (0-250 ka, $\mathrm{n}=11$ / class) and from the entire record (0-1.2 Ma, $\mathrm{n}=41 / \mathrm{class})$ (modified from Wagner et al. [2003]).

during OIS 7 with TOC, $1 \mathrm{~m} / \mathrm{hm}$, and $\mathrm{C}_{\text {org }} / \mathrm{C}_{\text {org }}$ * ratios and oppose the $\Lambda_{8 / 6}$ record indicating higher amounts of autochthonous OM for TOC maxima. During OIS 8 these relations are reversed. Elevated proportions of soil $\mathrm{OM}$ from a $\mathrm{C}_{4}$ habitat around $270 \mathrm{ka}$ and eolian supply of black carbon at $250 \mathrm{ka}$ may explain these changes.

[28] Following the general assignment of two different groups being separated according to their bulk OM reactivity ( $\mathrm{lm} / \mathrm{hm}$ of 2 , Figure 7$)$, Group-I samples (corresponding to fresh terrigenous and autochthonous $\mathrm{OM}$, and soil $\mathrm{OM}$ ) characterize periods of peak TOC deposition and thus periods of rapid change from dry to humid climate (the transition from insolation minima to maxima). This pattern is consistent throughout both time slices investigated in detail, except for one TOC maximum at the transition from glacial stage 8 to interglacial stage 7 (250 ka, Figure 9) where OM reactivity remains below that threshold. In contrast, a dominance of soil $\mathrm{OM}$ with variable enrichment of BC (Group-II samples) is linked to low TOC and humid or transitional climatic conditions (insolation maxima and transition to insolation minima).

\section{Discussion}

\subsection{Assessing the Nature of Sedimentary Organic Matter in Marine Sediments Using Conventional Bulk Parameters $\left(\mathrm{C}_{\text {org }} / \mathrm{N}_{\text {tot }}\right.$, Bulk $\delta^{13} \mathrm{C}_{\text {org }}$ ) and Lignin: Principles and Pitfalls Relevant to This Study}

[29] $\mathrm{OM}$ from marine or lacustrine production and from terrigenous vascular land plant sources display sharp general contrasts in their isotopic signature ${ }_{\text {bulk }} \delta{ }^{13} \mathrm{C}_{\mathrm{org}}{ }^{*}$ ) as well as in their ratios of organic carbon and total nitrogen $\left(\mathrm{C}_{\text {org }} / \mathrm{N}_{\text {tot }}\right.$, Figure 1$)$. Since both parameters are easy to analyse, they are frequently used to estimate contributions of autochthonous (marine or lacustrine) versus allochthonous (terrigenous) $\mathrm{OM}$ in aquatic sediments. Numerous investigations have demonstrated the utility of these parameters for continental paleoecological reconstructions using limnic sediments from different climate zones [e.g., Orem et al., 
1997; Meyers and Lallier-Vergès, 1999; Hu et al., 1999; Filley et al., 2001]. Compared to oceanic settings, lakes and their surroundings form more or less closed regional ecosystems where geochemical signals corresponding to changes in vegetation type and primary production in response to climate variations are directly transferred to sedimentary $\mathrm{OM}$ due to high accumulation rates and short transport distances. In contrast, interpretation of bulk $\delta{ }^{13} \mathrm{C}_{\text {org }}$ values and $\mathrm{C}_{\text {org }} / \mathrm{N}_{\text {tot }}$ ratios in marine settings is generally not as straightforward [Tyson, 1995; Meyers, 1997; Wagner and Dupont, 1999; Twichell and Meyers, 2002]. However, there are a number of applications providing plausible results within their individual geological context using this approach, e.g., from the Congo deep-sea fan [Müller et al., 1994], the Washington margin [Prahl et al., 1994], and the Gulf of Mexico [Hedges and Parker, 1976]. Interpretation of both parameters in the marine geological record, however, is more problematic due to potentially severe modifications of both parameters related to the heterogeneous multicomponent nature of the OM, varying susceptibilities to degradation, and specific characteristics of the sedimentary setting (e.g., grain sizes of lithogenic and organic particles or the influence of benthic fauna). The latter factors usually change considerably as climate and depositional conditions evolve, adding uncertainty to the definition (or recognition) of appropriate endmembers. Goñi et al. [1998], for example, suggest that terrigenous $\mathrm{OM}$ in surface sediments from the northwestern Gulf of Mexico may have been significantly underestimated in previous studies when $\mathrm{C}_{\text {org }} / \mathrm{N}_{\text {tot }}$ ratios and bulk $\delta^{13} \mathrm{C}_{\text {org }}$ signatures were used to define marine and terrigenous endmembers. They found that a significant part of the terrigenous $\mathrm{OM}$ derives from ${ }^{13} \mathrm{C}$-enriched $\mathrm{C}_{4}$ plant matter that results in a terrigenous $\mathrm{OM}$ signature that is virtually indistinguishable from marine OM. A recently published study on surface sediment samples from the inner Louisiana shelf imposingly demonstrates that massive supply of soil OM (and $\mathrm{C}_{4}$ plant matter) through the Atchafalaya River masks actual terrigenous $\mathrm{OM}$ proportions when two-end-member mixing models are applied on $\mathrm{C}_{\text {org }} / \mathrm{N}_{\text {tot }}$ ratios and bulk $\delta^{13} \mathrm{C}_{\text {org }}$ values [Gordon and Goñi, 2003]. The authors found that soil derived $\mathrm{OM}$ in fact is the dominating organic compound in deltaic, inshore and offshore sediments, and conclude that a two-end-member model underestimates the amount of terrigenous $\mathrm{OM}$ by 40 to $85 \%$. A similar, although less pronounced effect may be assumed for sediments deposited along the continental margin between the Congo and the Niger, considering that both rivers drain parts of the main African $\mathrm{C}_{4}$-plant habitat (Review and Atlas of Palaeovegetation, available at www.soton. ac.uk/ tjms/afrpres.gif) [Giresse et al., 1994].

[30] Apart from isotopic shifts related to a varying primary composition of bulk OM, selective microbial degradation may also bias the bulk isotopic signal. Freudenthal et al. [2001], for example, observed increasing bulk $\delta^{13} \mathrm{C}_{\text {org }}$ values with increasing diagenesis in sediments from the eastern subtropical Atlantic and point to the highly problematic estimation of marine and terrigenous amounts of bulk OM if both end-members are modified by fractionation. Comparable to the isotopic composition, $\mathrm{C}_{\mathrm{org}} / \mathrm{N}_{\text {tot }}$ ratios may also shift upon diagenesis, both prior to and post sedimentation. According to Hedges et al. [1986], degradation of terrigenous OM occurs primarily within the terrestrial environment. Dittmar and Lara [2001] observed sharply reduced $\mathrm{C}_{\text {org }} / \mathrm{N}_{\text {tot }}$ ratios ( $\sim 18)$ of particulate $\mathrm{OM}$ in mangrove sediments compared to fresh plant litter fall $\left(\mathrm{C}_{\mathrm{org}} / \mathrm{N}_{\text {tot }}=70\right)$ and postulate a relative enrichment of nitrogen during earliest degradation of leaf litter before its deposition. $\mathrm{C}_{\text {org }} / \mathrm{N}_{\text {tot }}$ ratios are not only determined by the relative proportions of terrigenous and marine $\mathrm{OM}$ (and their different susceptibilities to microbial degradation) but are additionally closely related to the grain size of both organic matter and sediment matrix [Hedges et al., 1997; Farella et al., 2001]. Ammonium released by microbial degradation of organic compounds (e.g., amino acids) can be fixed in the sediments when bound to clay minerals, while organic carbon is lost after respiration as $\mathrm{CO}_{2}$ or $\mathrm{CH}_{4}$. Schubert and Calvert [2001] also demonstrated the significant impact of nitrogen linked in the form of ammonium to clays of Arctic Ocean sediments leading to very low $\mathrm{C}_{\text {org }} /$ $\mathrm{N}_{\text {tot }}$ ratios. This ammonium has been bound to the clays on land, i.e., before the introduction to the 
aquatic environment as was confirmed by isotopic data.

[31] Poirier et al. [2002] investigated a tropical ancient soil from the Congo and indeed detected refractory $\mathrm{OM}$ and black carbon particles from incomplete combustion associated with finegrained minerals. Although some minor degradation may occur, $\mathrm{BC}$ potentially persists over long time spans in soils and sediments and thus has great potential to enter the geological record [Bird et al., 1999; Schmidt and Noack, 2000; Masiello and Druffel, 2001, 2003; Czimczik et al., 2003]. The $\mathrm{C}_{\text {org }} / \mathrm{N}_{\text {tot }}$ ratio of the bulk fine fraction $(<50 \mu \mathrm{m})$ in the Congo samples is 12.8 while the refractory material $(\mathrm{BC})$ is depleted in nitrogen $\left(\mathrm{C}_{\text {org }} / \mathrm{N}_{\text {tot }} \approx 20.1\right)$ [Poirier et al., 2002]. Bird et al. [1999] investigated samples of burned and unburned savannah soils from Zimbabwe. They observed increasing bulk $\delta^{13} \mathrm{C}_{\text {org }}$ values with decreasing particle size in both sample types, whereas in unburned samples the isotopic ratio was always 3-4\%o lower. Verardo and Ruddiman [1996] conclude that charcoal supply to deep-sea sediments of the tropical Atlantic reduces previous estimates of marine organic carbon burial fluxes by $50 \%$ (compare estimates in Wagner [2000] for the same area). In surface sediments of the northwestern Gulf of Mexico, Goñi et al. [1998] observe $\mathrm{C}_{\text {org }} / \mathrm{N}_{\text {tot }}$ ratios of 8 in sites shallower than $605 \mathrm{~m}$ water depth, and 6 to 5 in samples from deeper water. From the isotopic signatures of bulk OM the authors infer for significant supply of soil $\mathrm{OM}$ from the Mississippi drainage basin $\left(\mathrm{C}_{\text {org }} / \mathrm{N}_{\text {tot }}=10-13\right)$, much of which is dominated by grasslands (prairie), an important source of $\mathrm{C}_{4}$ plant debris. Onstad et al. [2000] draw similar conclusions based on measurements of suspended POM in the Mississippi river and its tributaries. These authors also argue that ${ }^{13} \mathrm{C}$ rich and lignin-poor particulate $\mathrm{OM}$ from soils makes it difficult to distinguish terrigenous from marine OM inputs.

[32] Ruttenberg and Goñi [1997] measured $\mathrm{C}_{\mathrm{org}} /$ $\mathrm{N}_{\text {tot }}$ ratios in Amazon shelf sediments ranging from 5 to 7. As fine suspended matter from the Amazon river has $\mathrm{C}_{\text {org }} / \mathrm{N}_{\text {tot }}$ values of 10 to 11 and furthermore important sorption of inorganic nitrogen (ammonium) by clay minerals was ruled out, the authors conclude that nitrogen must have been enriched after burial. They suggest a significant contribution of bacteria and their remains to the bulk organic pool. Bacteria have $\mathrm{C}_{\text {org }} / \mathrm{N}_{\text {tot }}$ ratios of 4 to 6 [e.g., Goñi and Hedges, 1995] and thus may lower the $\mathrm{C}_{\text {org }} / \mathrm{N}_{\text {tot }}$ values especially in fine-grained sediments where bacteria consuming organisms (e.g., protozoans) are less abundant. Additionally, bacteria have highly variable $\delta^{13} \mathrm{C}_{\mathrm{org}}$ signatures, their isotopic composition tends to reflect their dominant food source [Fry and Sherr, 1984]. Regarding these findings, Ruttenberg and Goñi [1997] conclude that two-end-member models are not suitable for estimations of marine and terrigenous OM contributions in sediments from the Gulf of Mexico and the Amazon shelf. However, these parameters, when measured in parallel, may provide important information on the complex nature of sedimentary OM.

[33] Lignin, a principle structural component of higher plant tissues, serves as a diagnostic tracer of terrigenous $\mathrm{OM}$ in marine environments and is commonly considered to be resistant to microbial degradation [e.g., Hedges and Mann, 1979b; Hedges and Ertel, 1982; Tissot and Welte, 1984]. Furthermore, variations in the composition of eight specific lignin-derived phenols provide means to distinguish between the most important types of plant tissue. Down-core variations may thus provide information about past vegetation and climate changes. Investigation of lignin phenols is progressively used in paleoenvironmental research since its early introduction [Hedges and Parker, 1976; Hedges and Mann, 1979a, 1979b]. The $\mathrm{S} / \mathrm{V}$ and $\mathrm{C} / \mathrm{V}$ ratios provide information on angiosperm or gymnosperm, non-woody or woody vascular plant tissues, respectively. Numerous investigations from different limnic and marine settings discuss lignin data (e.g., see list of selected applications to modern marine environments in Wagner et al. [2003]). Some of them emphasize that lignin is sensitive to degradation, selective decay, and mild thermal stress [e.g., Ishiwatari and Uzaki, 1987; Opsahl and Benner, 1995; Cody and Sághi-Szabó, 1999; Dittmar and Lara, 2001] supporting the concept that the ratios of vanillic acid to vanillin, $(\mathrm{Ad} / \mathrm{Al})_{\mathrm{V}}$, and syringic acid to 
syringaldehyde, $(\mathrm{Ad} / \mathrm{Al})_{\mathrm{S}}$, are suitable to assess the degree of lignin degradation.

\subsection{The Land-Ocean and Climate Linkage on the Congo Deep-Sea Fan}

[34] The results from this study demonstrate the importance of terrigenous OM from different continental sources in late Quaternary sediments at ODP Site 1075 on the Congo deep-sea fan. They challenge the widely held assumption that TOC maxima in late Quaternary sediments from the equatorial Atlantic continental margin reflect maxima in primary production, the driving force being trade wind-induced upwelling and nutrient supply from intermediate waters [e.g., Schneider et al., 1997b]. This conclusion, however, mainly stems from bulk $\delta^{13} \mathrm{C}_{\text {org }}$ data interpretation assuming a binary mixing model for marine and terrigenous OM (i.e., terrigenous OM exclusively from $\mathrm{C}_{3}$ sources). Schneider et al. [1997b] identify riverine nutrient supply as the driving force for marine primary production in the Congo highproductivity area. It may therefore be reasonable to expect at least some admixture of $\mathrm{OM}$ from riverine sources in the sediments, and thus has been confirmed for surface sediments from the Congo fan and the adjacent upper continental margin between Congo and Cameroon [Wagner et al., 2003].

[35] The observed relationships between compositional changes, level of reactivity and degradation of bulk OM, and their variability over time provide means to identify principle sources of OM and the definition of a succession of events that explains organic sedimentation at ODP site 1075 as a function of insolation forcing (Figure 11). The combination of data from lignin chemistry, bulk elemental analysis and pyrolysis, and bulk carbon isotopes indicates the presence of $\mathrm{OM}$ from at least three different sources: (1) marine (including bacterial) OM, (2) fresh and reactive, lignin-rich terrigenous OM (POM), and (3) lignin- and black carbon-bearing soil OM. Fluctuations in the relative proportions of these primary contributors result in systematic fluctuations in TOC and bulk OM reactivity with overall variability being closely linked to insolation-driven environmental change in central Africa and the adjacent easternmost Equatorial Atlantic. The close relation of bulk $\mathrm{OM}$ reactivity and soil $\mathrm{OM}$ implicates riverine supply as a key mechanism that determines not only the nature of $\mathrm{OM}$ in the sediments but also continental nutrient supply and thus primary production along the eastern Equatorial Atlantic continental margin.

\subsubsection{The Transition From Humid to Arid African Climate}

[36] Relatively non-reactive, soil-rich OM(Group-II samples) and corresponding low TOC characterize warm and humid climates (insolation maxima and decreasing insolation) and the transitional stage from humid to arid climate conditions at Site 1075. These properties apparently correspond to warm and wet climatic conditions in central Africa. A strongly developed monsoonal system during this orbital configuration fostered extension of the Congo rain forest with its dominant $\mathrm{C}_{3}$ vegetation. The invigorated hydrologic cycle also enhanced run-off to the adjacent tropical African continental margin. Owing to the enhanced continental nutrient supply, marine productivity should have been relatively high during these conditions. One of the most important nutrients for the dominant group of primary producers off the Congo, marine diatoms [van Bennekom and Berger, 1984], is dissolved silicate from river-outflow and/or upwelling supply [Schneider et al., 1997b; E. Uliana, C. B. Lange, and G. Wefer, Evidence for Congo freshwater load in Late Quaternary sediments of ODP Site $1077\left(5^{\circ} \mathrm{S}, 10^{\circ} \mathrm{E}\right)$, manuscript submitted to Palaeogeography, Palaeoclimatology, Palaeoecology, 2003]. Notably, marine taxa account for $95 \%$ of the siliceous microfossil assemblage [Uliana et al., 2001]. On the other hand, the massive suspension load of the river from intensive erosion of tropical soils in the hinterland probably hampered primary productivity by haze of the surface water in the river plume and a diminished translucence. At least, a stronger dilution of labile marine OM leading to a subdued productivity signal may be expected. It may also be speculated that degraded soil $\mathrm{OM}$ associated with the fine-grained lithogenic fraction was not a main nutrient source for marine primary 


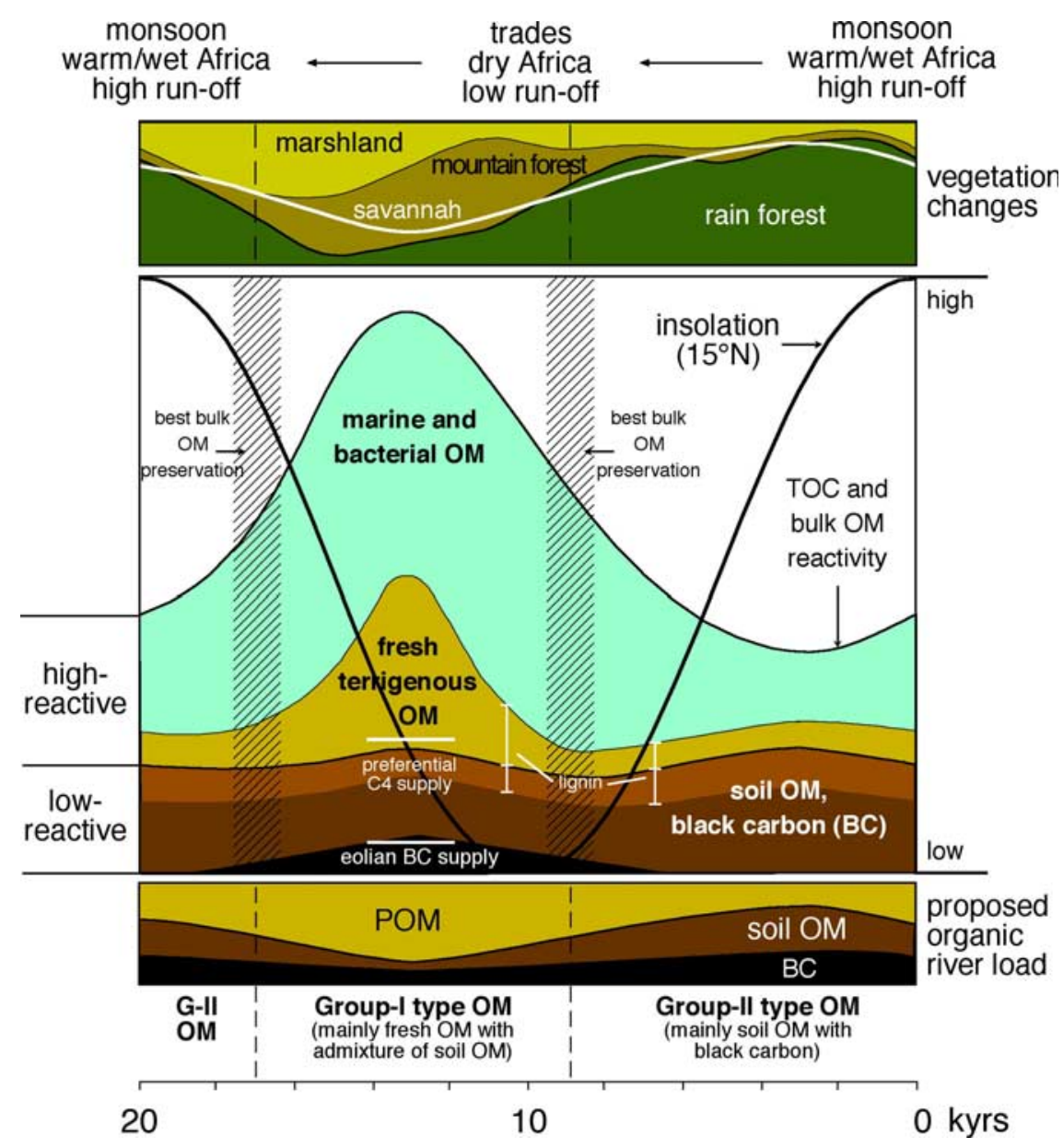

Figure 11. Conceptual model of organic matter sedimentation and preservation at the Congo deep-sea fan related to cyclic changes of insolation and vegetation. Palynological data from the Congo fan [Wagner et al., 2003] suggests expansion of savannah (white line in the top) and increasing aridity within the Congo catchment during and 2-6 kyrs after the insolation minimum by reduced pollen from rain forest and elevated contribution from Afromontane forests. Enhanced proportions of pollen from marsh and swamp areas mark the transition to humid conditions. Maximum TOC content and bulk OM reactivity is observed in sediments that accumulated during arid African climates at maximum savannah expansion, intense upwelling off the Congo, highest relative proportions of POM (fresh terrigenous $\mathrm{OM}$ ) in the river suspension load, and minimum supply of soil OM (Group-I samples). Opposite, the highest concentration of soil OM occurs 2-4 kyrs following the insolation maximum and results from dilution of marine OM and terrigenous POM and intense degradation of these reactive fractions. During this interval humid conditions and greatest expansion of rain forest with enhanced soil formation, weathering, and runoff prevailed. Best preservation of bulk OM occurs during the transitional stages, mainly from river- and upwelling-induced to pure river-induced primary production, short time before the insolation extremes and probably due to optimum balanced relations of labile $\mathrm{OM}$ and fluvial sediment supply. Changes of the relative contents of $\mathrm{BC}$ within the soil $\mathrm{OM}$ fraction are based on literature data suggesting that $\mathrm{BC}$ production was enhanced during arid periods with extended savannah vegetation compared to humid stages. Accordingly, quantitative estimates of $\mathrm{BC}$ cannot be given.

producers (as e.g., dissolved silica) but may have favoured the development of benthic micro-fauna. In fact, most of the marine OM has apparently been degraded as indicated by highest levels of bulk $\mathrm{OM}$ degradation (i.e., $\mathrm{C}_{\text {org }} / \mathrm{C}_{\text {org }}{ }^{*}$ as low as $0.55)$, leading to the observed dominant terrigenous organic signature in the sedimentary record and finally resulting in TOC minima. BC-bearing soil OM comprising the principle organic fraction in the sediments also determines the observed very low bulk OM reactivity $(\mathrm{lm} / \mathrm{hm}$ ratios as low as 0.2$)$. It has been shown that formation of $\mathrm{BC}$ is not only restricted to arid climate but also occurs during humid conditions as natural part of rain 
forest ecosystems [Schmidt and Noack, 2000]. The relative proportions of $\mathrm{BC}$ in the soil fraction of Congo fan sediments may therefore be variable, depending on the type of vegetation they originate from $\left(\mathrm{C}_{3}\right.$ versus $\left.\mathrm{C}_{4}\right)$, however, they are not quantified in this study. Kuhlbusch et al. [1996] estimate that $90 \%$ of the fire-derived $\mathrm{BC}$ remains on the ground. We therefore assume that most part of $\mathrm{BC}$ in Congo fan deposits is introduced as part of the fluvial soil OM fraction and not from eolian transport. Nevertheless, elevated contents of BC within the soil fraction may only be expected during maximum expansion of the African savannah.

[37] This study does not provide direct evidence or source-specific biomarkers for soil OM. However, the consistency of bulk OM parameters strongly supports the presence and importance of such an organic component. Fine-grained soil OM is often enriched in nitrogen $\left(\mathrm{C}_{\mathrm{org}} / \mathrm{N}_{\text {tot }} \approx 12\right)$ compared to coarse-grained POM, mostly associated with finegrained minerals, depleted in lignin, and the remaining lignin is severely degraded [Prahl et al., 1994; Hedges et al., 1986; Hedges and Oades, 1997; Keil et al., 1998]. C/V ratios of lignin from soils are generally low, whereas degradation-sensitive $(\mathrm{Ad} / \mathrm{Al})_{\mathrm{V}}$ parameters are enhanced [Farella et al., 2001]. It has been shown that a significant proportion of soil $\mathrm{OM}$ may be $\mathrm{BC}$, especially, where the overlying vegetation is affected of periodic burning [Bird et al., 1999; Schmidt and Noack, 2000; Poirier et al., 2002]. These burned components are depleted in nitrogen, enriched in the heavy carbon isotope, and have lowest concentration of lignin compared to bulk soil OM or $\mathrm{POM}$. If soil OM with low or moderate contents of $\mathrm{BC}$ account for a significant proportion of the bulk OM in Congo fan sediments, low $\mathrm{C}_{\text {org }} / \mathrm{N}_{\text {tot }}$ and $\mathrm{C} / \mathrm{V}$ ratios but elevated $(\mathrm{Ad} / \mathrm{Al})_{\mathrm{V}}$ values may be expected. One example is clearly recorded at $106 \mathrm{ka}$ (transition to full humid climate conditions, Figure 8). Here, very low $\mathrm{C}_{\text {org }} / \mathrm{N}_{\text {tot }}, \mathrm{lm} / \mathrm{hm}$ and $\mathrm{C} / \mathrm{V}$ ratios but high lignin yields and light bulk isotopic ratios support the presence of soil $\mathrm{OM}$ from $\mathrm{C}_{3}$ vegetation as a main source of lignin and a major component of the bulk OM. A distinct shift to very high $\mathrm{C}_{\text {org }} / \mathrm{N}_{\text {tot }}$ ratios during the following humid conditions $(101 \mathrm{ka})$ in combination with heavier bulk isotopic signatures (caused by the inert fraction) and elevated $\mathrm{C} / \mathrm{V}$ ratios and lignin contents suggest a progressive increase in soil-associated $\mathrm{BC}$, as well as enhanced admixture of nitrogenpoor POM from rain forest vegetation at that time.

[38] The observed relative enrichment of soil OM in Group-II samples is supported by low reactivity of the remaining bulk OM, elevated lignin yields, and low $\mathrm{C} / \mathrm{V}$ and $\mathrm{C}_{\text {org }} / \mathrm{N}_{\text {tot }}$ ratios (e.g., at $237 \mathrm{ka}$ and $244 \mathrm{ka}$, Figure 9). The lighter isotopic ratios $(\sim-21.5 \%$ ) suggests the preferential supply of soil from $\mathrm{C}_{3}$ habitats at $237 \mathrm{ka}$, whereas the $1 \%$ heavier isotopic signature at $244 \mathrm{ka}$ supports an origin of soil $\mathrm{OM}$ from $\mathrm{C}_{4}$-type vegetation associated with the transition from arid to more humid conditions.

[39] The environmental conditions changed rapidly with the progressive decrease in insolation and aridification of central Africa. According to the palynological data [see Wagner et al., 2003] rain forest cover receded and the relative supply of pollen from the Afromontan forests (dominated by Podocarpus) increased parallel to the expansion of savannah vegetation [Dupont et al., 2000]. Synchronous with the transition from a monsoonal to a trade wind-dominated atmospheric circulation, upwelling was enhanced and stimulated marine productivity in the Congo high productive area, the main nutrient source for primary production changing from riverine supply to wind-induced upwelling about 6 to 8 kyrs following the insolation maximum. Notably, a short time before the insolation minimum, contributions of continental OM dropped to their lowest level (Figure 11). The diminished availability of reactive $\mathrm{OM}$ from marine primary production and/or terrigenous supply apparently suppressed microbial activity in the sediment, the result being enhanced preservation of marine $\mathrm{OM}$ as indicated by highest $\mathrm{C}_{\mathrm{org}} / \mathrm{C}_{\mathrm{org}}$ * .

\subsubsection{Transition From Arid to Humid African Climate}

[40] During the phase of maximum savannah expansion, supply of soil OM approached its minimum whereas the amount of POM in the terrigenous organic fraction was relatively 
enhanced. Samples from arid climates are therefore dominated by Group-I OM. The bulk OM reactivity (expressed as the $1 \mathrm{~m} / \mathrm{hm}$ ratio) and concentration (TOC) remains high during this interval, mainly due to significant amounts of POM and marine OM. While the supply of soil OM was relatively low under these conditions, its $\mathrm{BC}$ concentration may have approached highest proportions taking lower biomass production and a probably increased number of bush fires within the extended savannah areas into account. In view of enhanced aridity and stronger trade winds, an additional source of $\mathrm{BC}$ may have been the central and southern African $\mathrm{C}_{4}$ habitats, the primary transport mechanism being eolian supply [Verardo and Ruddiman, 1996]. Eglinton et al. [2002] studied one dust sample collected off NW-Africa and Huang et al. [2000] mapped the abundance of ${ }^{13} \mathrm{C}$ in leaf-wax components in surface sediments recovered from the seafloor off northwest Africa $\left(0-35^{\circ} \mathrm{N}\right)$ both revealing a clear pattern of $\delta^{13} \mathrm{C}$ distribution, indicating systematic changes in the proportions of terrestrial $\mathrm{C}_{3}$ and $\mathrm{C}_{4}$ plant input. The latter authors conclude that $\mathrm{C}_{4}$ plant derived terrigenous leave-waxes achieve highest proportions $(>50 \%)$ off the NW-African coast at about $20^{\circ} \mathrm{N}$. Using a comparable approach, Schefu $\beta$ et al. [2003] found that more than $50 \%$ of n-alkanes from plant waxes in surface sediments of the Congo and Angola Basins derive from $\mathrm{C}_{4}$ plants and infer for an increased eolian supply from southern African grasslands. In the Congo river, reduced amounts of fine-grained suspension from soil erosion and enhanced relative proportions of fresh POM within the river load in combination with strong upwelling along the Equatorial Atlantic continental margin effectively stimulated marine productivity off the Congo, as is documented by a pronounced maximum in TOC. Increasing humidity following full arid climatic conditions in central Africa was certainly accompanied by a major re-draining of the former savannah-covered habitats in the surrounding of the Congo catchment and the rain forest itself that should have resulted in an enhanced supply of POM from $\mathrm{C}_{4}$ habitats. Elevated relative amounts of Cyperaceae pollen (mainly sedges and rushes) go along with rising humidity. The presence of this pollen type suggests more extensive marshlands and swamps in flat areas and along the rivers [Dupont et al., 2001]. With further increasing insolation and humidity, the rainforests expanded again, and the influence of the monsoonal system on organic sedimentation on the Congo fan progressively recovered to its initial configuration. This general change in atmospheric circulation caused the recession of upwelling processes in the eastern tropical Atlantic. 2-4 kyrs before the insolation maximum reduced primary production and relatively low concentrations of reactive terrigenous $\mathrm{OM}(\mathrm{POM})$ in the river load are balanced with increasing soil supply resulting in reduced microbial activity in the sediments (comparable to the situation 2-4 kyrs before the insolation minimum). A better preservation of marine $\mathrm{OM}$ during this intermediate climate stage is indicated by high $\mathrm{C}_{\mathrm{org}} / \mathrm{C}_{\mathrm{org}}$ * ratios. Following a further increase of continental humidity, weathering, and run-off the sedimentation of lignin-rich soil $\mathrm{OM}$ primarily from $\mathrm{C}_{3}$ habitats (Group-II samples) one more time took the lead as a primary proportion of the bulk $\mathrm{OM} \sim 2$ kyrs before the insolation maximum.

[41] The data presented propose two maxima in primary productivity. One during stages of enhanced trade-forced upwelling (arid African climate) and a second during monsoonal stages and enhanced fluvial nutrient supply (humid African climate). This is consistent with results from investigations of modern [van Bennekom and Berger, 1984] and past [Schneider et al., 1997b; Uliana et al., 2001] productivity off the Congo. Accordingly, reactive marine $\mathrm{OM}$ is diluted by massive delivery of soil material (containing low-reactive OM) during the humid stage, but at the same time stimulates intensive microbial degradation in the sediment which finally results in lowest TOC concentrations. This coherency may also explain the observed noncorrelation between TOC and biogenic opal as productivity proxy for marine diatoms $\left(\mathrm{r}^{2}=0.002\right.$ at Site 1075 and $\mathrm{r}^{2}=0.05$ at Site 1077, Holtvoeth, unpublished data).

\section{Conclusions}

[42] Primary productivity in the late Quaternary eastern equatorial Atlantic off the Congo is stimu- 
lated by strong nutrient supply in response to tradeinduced upwelling during arid African climates and by massive fluvial nutrient delivery during humid climate stages, both resulting from precessional controlled changes of insolation and atmospheric circulation (monsoon versus trade winds). However, the fluvial contribution of fine-grained lithogenic suspension from OM-rich soils appears to be a decisive factor for the concentration and preservation of autochthonous (marine) OM. This conclusion is supported by the observed 2-4 kyrs time shift of bulk organic-geochemical signatures that corresponds to the delayed development of vegetation and soil with respect to atmospheric circulation and insolation. It may be speculated that the supply of clay-size lithogenic matter fostered scavenging effects and the interaction of mineral surfaces with the labile organic fraction. These mechanisms should have amplified the flux and burial rates of reactive OM but, on the other hand, should also have promoted the growth of benthic and bacterial communities and thus degradation of labile OM. Most favourable conditions for the preservation of bulk OM occurred during intermediate climate stages when moderate upwelling was combined with a balanced fluvial supply of soil material and POM.

[43] The data reveal that varying organic-geochemical properties in Congo fan sediments can neither be explained by changes in upwelling- and riverinduced primary production, fluvial OM supply, and OM burial rates nor by the degree of selective $\mathrm{OM}$ degradation. Massive fluvial contribution of fine-grained soil material with significant amounts of low-reactive $\mathrm{OM}$ as well as $\mathrm{BC}$ is indicated by bulk parameters $\left(\mathrm{C}_{\text {org }} / \mathrm{N}_{\text {tot }}, 1 \mathrm{~m} / \mathrm{hm}\right)$ and results from lignin analysis $\left(\mathrm{C} / \mathrm{V}, \Lambda_{8}, \mathrm{Ad} / \mathrm{Al}_{\mathrm{V}}\right)$. These components apparently strongly determine bulk OM composition, concentration, and preservation. In fact, the residual TOC profile records only one of two former maxima in primary production. Correlation with other productivity proxies, e.g., concentrations of biogenic opal, is therefore complicated or impossible.

[44] Significant fluvial and/or eolian supply of soil $\mathrm{OM}$ and $\mathrm{BC}$ from $\mathrm{C}_{4}$ plant habitats especially during arid African climates may lead to a severe underestimation of terrigenous $\mathrm{OM}$ if binary mixing models are used for the interpretation of the bulk $\delta^{13} \mathrm{C}_{\text {org }}$ signal. Though ratios of stable carbon isotopes (bulk $\delta^{13} \mathrm{C}_{\text {org }}$ ) and $\mathrm{C}_{\text {org }} / \mathrm{N}_{\text {tot }}$ values of bulk OM apparently are not suitable to directly assess marine and terrigenous amounts both parameters bear substantial information on bulk $\mathrm{OM}$ quality and cyclic variations within the terrigenous fraction when combined with lignin data $\left(\Lambda_{8 / 6}\right.$, $\mathrm{C} / \mathrm{V}$, and $(\mathrm{Ad} / \mathrm{Al})_{\mathrm{V}, \mathrm{S}}$ ratios) and parameters characterizing bulk OM reactivity and degradation from Rock-Eval pyrolysis $(\mathrm{lm} / \mathrm{hm})$ and elemental analysis $\left(\mathrm{C}_{\text {org }} / \mathrm{S}_{\text {tot }}, \mathrm{C}_{\text {org }} / \mathrm{C}_{\text {org }}{ }^{*}\right)$.

\section{Acknowledgment}

[45] Technical assistance in the laboratories at Bremen was performed by I. Ebert, H. Heilmann, R. Henning, G. Klockgether, and M. Peters. We thank Timothy Eglinton (WHOI), Miguel Goñi (University of South Carolina), and Philip Meyers (University of Michigan) for critical and instructive comments on a former version of the manuscript. This research was funded by the Deutsche Forschungsgemeinschaft, grant Wa 1036/5, and kindly supported by the Max-Planck Society.

\section{References}

Bauer, J. E., and E. R. M. Druffel, Ocean margins as a significant source of organic matter to the deep open ocean, Nature, 392, 482-485, 1998.

Bird, M. I., C. Moyo, E. M. Veenendal, J. Lloyd, and P. Frost, Stability of elemental carbon in a savannah soil, Global Biogeochem. Cycles, 13, 923-932, 1999.

Cerling, T. E., J. M. Harris, B. J. MacFadden, M. G. Leakey, J. Quade, V. Eisenmann, and J. R. Ehleringer, Global vegetation change through the Miocene/Pliocene boundary, Nature, 389, 153-158, 1997.

Cody, G. D., and G. Sághi-Szabó, Calculation of the ${ }^{13} \mathrm{C}$ NMR chemical shift of ether linkages in lignin derived geopolymers: Constraints on the preservation of lignin primary structure with diagenesis, Geochim. Cosmochim. Acta, 63, 193-205, 1999.

Czimczik, C. I., C. M. Preston, M. W. Schmidt, and E. Schulze, How surface fire in Sibirian Scots pine forests affects soil organic carbon in the forest floor: Stocks, molecular structure, and conversion to black carbon (charcoal), Global Biogeochem. Cycles, 17(1), 1020, doi:10.1029/2003GC000590, 2003.

DeMenocal, P. B., Plio-Pleistocene African climate, Science, 270, 53-59, 1995.

Dittmar, T., and R. J. Lara, Molecular evidence for lignin degradation in sulfate-reducing mangrove sediments (Amazonia, Brazil), Geochim. Cosmochim. Acta, 65, 1417-1428, 2001. 
Dupont, L. M., Pollen and spores in marine sediments from the East Atlantic. A view from the ocean into the African continent, in The Use of Proxies in Paleoceanography: Examples from the South Atlantic, edited by G. Fischer and G. Wefer, pp. 523-546, Springer-Verlag, New York, 1999.

Dupont, L. M., S. Jahns, F. Marret, and S. Ning, Vegetation change in equatorial West Africa: Time-slices for the last 150 ka, Palaeogeogr. Palaeoclimatol. Palaeoecol., 155, 95-122, 2000.

Dupont, L. M., B. Donner, R. Schneider, and G. Wefer, MidPleistocene environmental change in tropical Africa began as early as 1.05 Ma, Geology, 29, 195-198, 2001.

Eglinton, T. I., and D. J. Repeta, Organic matter in the contemporary ocean, in Treatise on Geochemistry, vol. 155, edited by H. Elderfield, Pergamon, New York, 2003.

Eglinton, T. I., G. Eglinton, L. Dupont, E. R. Sholkovitz, D. Montluçon, and C. M. Reddy, Composition, age, and provenance of organic matter in NW African dust over the Atlantic Ocean, Geochem. Geophys. Geosyst., 3(8), 1050, doi:10.1029/2003GC000590, 2002.

Eisma, D., Supply and dispersal of suspended matter from the Zaire River, Mitt. Geol.-Paläont. Inst., Univ. Hamburg, SCOPE/UNEP Sonderband Heft, 52, 419-428, 1982.

Espitalié, J., J. L. Laporte, M. Madec, F. Marquis, P. Leplat, J. Paulet, and A. Boutefeu, Methode radide de characterisation des roches-mere, de leur potential petrolier et de leur degre d'evolution, Rev. Inst. Fr. Pet., 32, 23-42, 1977.

Espitalié, J., G. Deroo, and F. Marquis, La pyrolyse Rock-Eval et ses applications, Rev. Inst. Fr. Pet., 40, 25-89, 1985.

Farella, N., M. Lucotte, P. Louchouarn, and M. Roulet, Deforestation modifying terrestrial organic transport in the Rio Tapajós, Brazilian Amazon, Org. Geochem., 32, 14431458, 2001.

Filley, T. R., K. H. Freemen, T. S. Bianchi, M. Baskaran, L. A. Colarusso, and P. G. Hatcher, An isotopic biogeochemical assessment of shifts in organic matter input to Holocene sediments from Mud Lake, Florida, Org. Geochem., 32, $1153-1167,2001$.

Frédoux, A., Pollen analysis of a deep- sea core in the Gulf of Guinea: Vegetation and climatic changes during the last 225,000 years B. P., Palaeogeogr. Palaeoclimatol. Palaeoecol., 109, 317-330, 1994.

Freudenthal, T., T. Wagner, F. Wenzhöfer, M. Zabel, and G. Wefer, Early diagenetic changes of sedimentary stable nitrogen and carbon isotope ratios, Geochim. Cosmochim. Acta, 65, 1795-1808, 2001.

Fry, B., and E. B. Sherr, $\delta^{13} \mathrm{C}_{\mathrm{org}}$ measurements as indicators of carbon flow in marine and freshwater ecosystems, Contrib. Mar. Sci., 27, 13-47, 1984.

Giresse, P., J. Maley, and P. Brenac, Late Quaternary palaeoenvironments in the Lake Barombi Mbo (West Cameroon) deduced from pollen and carbon isotopes of organic matter, Palaeogeogr. Plaeoclimatol. Palaeoecol., 107, 65-78, 1994.

Goñi, M. A., and J. I. Hedges, Lignin dimers: Structures, distribution, and potential geochemical applications, Geochim. Cosmochim. Acta, 56, 4025-4043, 1992.

Goñi, M. A., and J. I. Hedges, Sources and reactivities of marine-derived organic matter in coastal sediments as deter- mined by alkaline $\mathrm{CuO}$ oxidation, Geochim. Cosmochim. Acta, 59, 2965-2981, 1995.

Goñi, M. A., K. C. R. Ruttenberg, and T. I. Eglinton, A reassessment of the sources and importance of land-derived organic matter in surface sediments from the Gulf of Mexico, Geochim. Cosmochim. Acta, 62, 3055-3075, 1998.

Gordon, E. S., and M. A. Goñi, Sources and distribution of terrigenous organic matter delivered by the Atchafalaya River to sediments in the northern Gulf of Mexico, Geochim. Cosmochim. Acta, 67, 2359-2375, 2003.

Hartnett, H. E., R. G. Keil, J. I. Hedges, and A. H. Devol, Influence of oxygen exposure time on organic carbon preservation in continental margin sediments, Nature, 391, 572-574, 1998.

Hedges, J. I., and J. R. Ertel, The lignin geochemistry of a late Quaternary sediment core from lake Washington, Geochim. Cosmochim. Acta, 46, 1869-1877, 1982.

Hedges, J. I., and D. C. Mann, The characterization of plant tissues by their lignin oxidation products, Geochim. Cosmochim. Acta, 43, 1803-1807, 1979a.

Hedges, J. I., and D. C. Mann, The lignin geochemistry of marine sediments from the southern Washington coast, Geochim. Cosmochim. Acta, 43, 1809-1818, 1979b.

Hedges, J. I., and J. M. Oades, Comparative organic geochemistries of soils and marine sediments, Org. Geochem., 27, 319-361, 1997.

Hedges, J. I., and P. L. Parker, Land-derived organic matter in surface sediments from the Gulf of Mexico, Geochim. Cosmochim. Acta, 40, 1019-1029, 1976.

Hedges, J. I., W. A. Clark, P. D. Quay, J. E. Richey, A. H. Devol, and U. D. M. Santos, Composition and fluxes of particulate organic material in the Amazon River, Limnol. Oceanogr., 31, 717-738, 1986.

Hedges, J. I., R. G. Keil, and R. Benner, What happens to terrestrial organic matter in the ocean?, Org. Geochem., 27, 195-212, 1997.

Holtvoeth, J., T. Wagner, B. Horsfield, C. J. Schubert, and U. Wand, Late-Quaternary supply of terrigenous organic matter to the Congo deep-sea fan (ODP Site 1075): Implications for equatorial African paleoclimate, Geo Mar. Lett., 21, 23-33, 2001.

Hu, F. S., J. I. Hedges, E. S. Gordon, and L. B. Brubaker, Lignin biomarkers and pollen in postglacial sediments of an Alaskan lake, Geochim. Cosmochim. Acta, 63, 14211430, 1999.

Huang, Y., R. A. Street-Parrott, P. Metzger, and G. Eglinton, Glacial-intergalcial environmental changes inferred from molecular and compound-specific $\delta^{13} \mathrm{C}$ analyses of sediments from Sacred Lake, Mt. Kenya, Geochim. Cosmochim. Acta, 63, 1383-1404, 1999.

Huang, Y., L. Dupont, M. Sarnthein, J. M. Hayes, and G. Eglinton, Mapping of C4 plant input from North West Africa into North East Atlantic sediments, Geochim. Cosmochim. Acta, 64, 3505-3513, 2000.

Ishiwatari, R., and M. Uzaki, Diagenetic changes of lignin compounds in a more than 0. 6 million-year-old lacustrine sediment (Lake Biwa, Japan), Geochim. Cosmochim. Acta, 51, 321-328, 1987. 
Jahns, S., M. Hüls, and M. Sarnthein, Vegetation and climate history of west equatorial Africa based on a marine pollen record off Liberia (site GIK 16776) covering the last 400,000 years, Rev. Palaeobot. Palynol., 102, 277-288, 1998.

Jolly, D., and A. Haxeltine, Effect of low glacial atmospheric $\mathrm{CO}_{2}$ on tropical African montane vegetation, Science, 276, 786-788, 1997.

Jones, R. W., Organic matter characteristics near the shelfslope boundary, SEPM Spec. Publ., 33, 391-405, 1983.

Jørgensen, B. B., Bacteria and marine biogeochemistry, in Marine Geochemistry, edited by H. D. Schulz and M. Zabel, pp. 173-207, Springer-Verlag, New York, 1999.

Keil, R. G., E. Tsamakis, J. C. Giddings, and J. I. Hedges, Biochemical distributions (amino acids, neutral sugars, and lignin phenols) among size-classes of modern marine sediments from the Washington coast, Geochim. Cosmochim. Acta, 62, 1347-1364, 1998.

Kuhlbusch, T. A. J., M. O. Andreae, H. Cachier, J. G. Goldammer, J.-P. Lacaux, R. Shea, and P. J. Crutzen, Black carbon formation by savannah fires: Measurements and implications for the global carbon cycle, J. Geophys. Res., 101, 23,651-23,665, 1996.

Littke, R., A. Lückge, and D. H. Welte, Quantification of organic matter degradation by microbial sulphate reduction for Quaternary sediments from the Northern Arabian Sea, Naturwissenschaften, 84, 312-315, 1997.

Martins, O., and J. L. Probst, Biogeochemistry of major African rivers: Carbon and mineral transport, in Biogeochemistry of Major World Rivers, edited by E. T. Degens, S. Kempe, and J. E. Richey, pp. 127-156, John Wiley, Hoboken, N. J., 1991.

Masiello, C. A., and E. M. Druffel, Carbon isotope chemistry of the Santa Clara river, Global Biogeochem. Cycles, 15, 407-416, 2001.

Masiello, C. A., and E. M. Druffel, Organic and black carbon ${ }^{13} \mathrm{C}$ and ${ }^{14} \mathrm{C}$ through the Santa Monica Basin sediment oxicanixic transition, Geophys. Res. Lett., 30(4), 1185, doi:10.1029/2003GC000590, 2003.

Meyers, P. A., Organic geochemical proxies of paleoceanographic, paleolimnologic, and paleoclimatic processes, Org. Geochem., 27, 213-250, 1997.

Meyers, P. A., and E. Lallier-Verges, Lacustrine sedimentary organic matter records of Late Quaternary paleoclimates, J. Paleoclimatol., 21, 345-372, 1999.

Müller, P. J., R. Schneider, and G. Ruhland, Late Quaternary $p \mathrm{CO}_{2}$ variations in the Angola Current: Evidence from organic carbon $\delta^{13} \mathrm{C}$ alkenone temperatures, in Carbon Cycling in the Glacial Ocean: Constraints on the Ocean's Role in Global Change, edited by R. Zahn et. al., pp. $343-$ 366, Springer-Verlag, New York, 1994.

Ning, S., and L. M. Dupont, Vegetation and climatic history of southwest Africa: A marine palynological record of the last 300,000 years, Vegetation Hist. Archaeobotany, 6, 17-131, 1997.

N'Kounkou, R. R., and J. L. Probst, Hydrology and geochemistry of the Congo River System, Mitt. Geol.-Paläont. Inst., Univ. Hamburg, SCOPE/UNEP Sonderband Heft, 64, 438508, 1987.
Onstad, G. D., D. E. Canfield, P. D. Quay, and J. I. Hedges, Sources of particulate organic matter in rivers from the continental USA: Lignin phenol and stable carbon isotope composition, Geochim. Cosmochim. Acta, 64, 3539-3546, 2000.

Opsahl, S., and R. Benner, Early diagenesis of vascular plant tissues: Lignin and cutin decomposition and biogeochemical implications, Geochim. Cosmochim. Acta, 59, 4889-4904, 1995.

Orem, W. H., S. M. Colman, and H. E. Lerch, Lignin phenols in sediments of Lake Baikal, Siberia: Application to paleoenvironmental studies, Org. Geochem., 27, 153-172, 1997.

Poirier, N., S. Derenne, J. Balesdent, J. N. Rouzaud, A. Mariotti, and C. Largeau, Abundance and composition of refractory organic fraction of an ancient, tropical peat soil (Point Noire, Congo), Org. Geochem., 33, 383-391, 2002.

Pokras, E. M., and A. C. Mix, Eolian evidence for spatial variability of Late Quaternary climates in tropical Africa, Quat. Res., 24, 137-149, 1985.

Prahl, F. G., J. R. Ertel, M. A. Goni, M. A. Sparrow, and B. Eversmeyer, Terrestrial organic carbon contributions to sediments of the Washington margin, Geochim. Cosmochim. Acta, 58, 3048-3053, 1994.

Rühlemann, C., M. Frank, W. Hale, A. Mangini, S. Mulitza, P. J. Müller, and G. Wefer, Late Quaternary productivity changes in the western equatorial Atlantic from ${ }^{230} \mathrm{Th}-$ normalized carbonate and organic carbon accumulation rates, Mar. Geol., 135, 127-152, 1996.

Rullkötter, J., Organic matter: The driving force for early diagenesis, in Marine Geochemistry, edited by H. D. Schulz and M. Zabel, pp. 129-172, Springer-Verlag, New York, 1999.

Ruttenberg, K. C., and M. A. Goñi, Posphorous distribution, $\mathrm{C}: \mathrm{N}: \mathrm{P}$ ratios, and $\delta^{13} \mathrm{C}_{\mathrm{oc}}$ in arctic, temperate, and tropical coastal sediments: Tools for characterizing bulk sedimentary organic matter, Mar. Geol., 139, 123-145, 1997.

Schefuß, E., S. Schouten, J. H. F. Jansen, and J. S. Sinninghe Damsté, African vegetation controlled by tropical sea surface temperatures in the mid-Pleistocene period, Nature, 422, 418-421, 2003.

Schlünz, B., and R. R. Schneider, Transport of terrestrial organic carbon to the oceans by rivers: Re-estimating fluxand burial-rates, Int. J. Earth Sci., 88, 599-606, 2000.

Schlünz, B., R. R. Schneider, P. J. Müller, W. J. Showers, and G. Wefer, Terrestrial organic carbon accumulation on the Amazon Deep Sea Fan during the last glacial sealevel lowstand, Chem. Geol., 159, 263-281, 1999.

Schmidt, M. W. I., and A. G. Noack, Black carbon in soils and sediments: Analysis, distribution, implications, and current challenges, Global Biogeochem. Cycles, 14, 777-793, 2000.

Schneider, R. R., P. J. Püller, and G. Wefer, Late Quaternary paleoproductivity changes off the Congo deduced from stable carbon isotopes of planktonic foraminifera, Palaeogeogr. Palaeoclimatol. Palaeoecol., 110, 255-274, 1994.

Schneider, R. R., P. J. Müller, B. Schlünz, M. Segel, W. J. Showers, and G. Wefer, Late Quaternary Western Atlantic paleoceanography and terrigenous sedimentation on the Amazon Fan: A view from $\delta^{18} \mathrm{O}$ and $\delta^{13} \mathrm{C}$ of planktonic 
foraminifera and bulk organic matter $\delta^{13} \mathrm{C}$, Proc. Ocean Drill. Program Sci. Results, 155, 1997a.

Schneider, R. R., P. J. Müller, D. Kroon, B. Price, and I. Alexander, Monsoon related variations in Zaire (Congo) sediment load and influence of fluvial silicate supply on marine productivity in the east equatorial Atlantic during the last 20,0000 years, Paleoceanography, 12, 463-481, 1997b.

Schubert, C. J., and S. E. Calvert, Nitrogen and carbon isotopic composition of marine and terrestrial organic matter in Arctic Ocean sediments: Implications for nutrient utilization and organic matter composition, Deep Sea Res., 48, 789-810, 2001.

Schubert, C. J., T. G. Ferdelman, G. Klockgether, and B. B. Jørgensen, Sulfate reduction rates and organic matter composition in sediments off Namibia, in Proceedings of the 10th international Symposium on Water-Rock Interaction, edited by R. Cidu, pp. 647-650, A. A. Balkema, Brookfield, Vt., 2001.

Showers, W. J., and D. G. Angle, Stable isotopic characterization of organic carbon accumulation on the Amazon continental shelf, Cont. Shelf Res., 6, 227-244, 1986.

Silva, J. A., and J. M. Bremner, Determination and isotoperatio analysis of different forms of nitrogen in soils. 5. Fixed ammonium, Soil Sci. Soc. Am. Proc., 30, 587-594, 1966.

Stein, R., and K. Fahl, Holocene accumulation of organic carbon at the Laptev Sea Continental Margin (Arctic Ocean): Sources, pathways, and sinks, Geo. Mar. Lett., 20, 27-36, 2000.

Stein, R., and R. W. Mcdonald, The Organic Carbon Cycle in the Arctic Ocean, Springer-Verlag, New York, 2003.

Tissot, B. P., and D. H. Welte, Petroleum Formation and Occurence, 699 pp. pp., Springer-Verlag, New York, 1984.

Twichell, S. C., P. A. Meyers, and L. Diester-Haass, Significance of high $\mathrm{C} / \mathrm{N}$ ratios in organic-carbon rich Neogene sediments under the Benguela Current upwelling system, Org. Geochem., 33, 715-722, 2002.

Tyson, R. V., Sedimentary Organic Matter: Organic Facies and Palynofacies, Chapman and Hall, New York, 1995.

Uliana, E., C. B. Lange, B. Donner, and G. Wefer, Siliceous phytoplankton productivity in the Congo Basin over the past
460,000 years: Marine vs. riverine influence, ODP Site 1077, in Proc. Ocean Drill. Program Sci., 175, 2001.

van Bennekom, A. J., and G. W. Berger, Hydrography and silica budget of the Angola Basin, Netherlands J. Sea Res., 17, 149-200, 1984.

Verardo, D. J., and W. F. Ruddiman, Late Pleistocene charcoal in tropical Atlantic deep-sea sediments: Climatic and geochemical significance, Geology, 24, 855-857, 1996.

Wagner, T., Pliocene-Pleistocene deposition of carbonate and organic carbon at Site 959: Paleoenvironmental implications for the eastern equatorial Atlantic off the Ivory Coast/Ghana, Proc. Ocean Drill. Program Sci. Results, 159, 1998.

Wagner, T., Petrology of organic matter in modern and Late Quaternary deposits of the Equatorial Atlantic: Climatic and oceanographic links, Int. J. Coal Geol., 39, 155-184, 1999.

Wagner, T., Control of organic carbon accumulation in the late Quaternary Equatorial Atlantic (ODP Sites 664, 663), Productivity versus terrigenous supply, Paleoceanography, 15, 181-199, 2000.

Wagner, T., and L. M. Dupont, Terrestrial organic matter in marine sediments: Analytical approaches and eolian-marine records from the central Equatorial Atlantic, in The Use of Proxies in Paleoceanography: Examples From the South Atlantic, edited by G. Fischer and G. Wefer, pp. 547-574, Springer-Verlag, New York, 1999.

Wagner, T., M. Zabel, L. M. Dupont, J. Holtvoeth, and C. J. Schubert, Terrigenous signals in sediments of the low latitude Atlantic - Implications for environmental variations during the Late Quaternary, Part I: Organic carbon, in The South Atlantic in the Late Quaternary: Reconstruction of Material Budgets and Current Systems, edited by G. Wefer, S. Mulitza, and V. Rathmeyer, Springer-Verlag, New York, in press, 2003.

Wefer, G., et al., Proceedings of the Ocean Drilling Program, Initial Reports, vol. 175, Ocean Drill. Program, College Station, Tex., 1998.

Zabel, M., T. Bickert, L. Dittert, and R. R. Haese, The significance of sedimentary $\mathrm{Al} / \mathrm{Ti}$ ratio as indicator for reconstructions of the terrestrial input to the Equatorial Atlantic, Paleoceanography, 14, 789-799, 1999. 